Article

\title{
Linking Spatial Patterns of Groundwater Table Dynamics and Streamflow Generation Processes in a Small Developed Catchment
}

\author{
Natalie Orlowski *, Florian Lauer, Philipp Kraft, Hans-Georg Frede and Lutz Breuer \\ Institute for Landscape Ecology and Resources Management, Research Centre for BioSystems, \\ Land Use and Nutrition (IFZ), Justus Liebig University Giessen, Heinrich-Buff-Ring 26, \\ Giessen 35392, Germany; E-Mails: florian.lauer@umwelt.uni-giessen.de (F.L.); \\ philipp.kraft@umwelt.uni-giessen.de (P.K.); hans-georg.frede@umwelt.uni-giessen.de (H.-G.F.); \\ lutz.breuer@umwelt.uni-giessen.de (L.B.) \\ * Author to whom correspondence should be addressed; \\ E-Mail: natalie.orlowski@umwelt.uni-giessen.de; Tel.: +49-641-99-37394; Fax: +49-641-99-37389.
}

External Editor: Miklas Scholz

Received: 19 June 2014; in revised form: 19 August 2014 / Accepted: 23 September 2014 /

Published: 15 October 2014

\begin{abstract}
Knowledge about water flow paths is essential for understanding biogeochemical fluxes in developed agricultural landscapes, i.e., the input of nutrients into surface waters, soil erosion, or pesticide fate. Several methods are available to study rainfall-runoff processes and flux partitioning: hydrometric based approaches, chemical tracers, modeling, and stable isotope applications. In this study a multi-method approach was conducted to gain insights into the hydrological fluxes and process understanding within the complex anthropogenic-influenced catchment of the Vollnkirchener Bach, Germany. Our results indicate that the catchment responds differently to precipitation input signals and dominant runoff-generation processes change throughout the year. Rainfall-induced runoff events during dry periods are characterized by a temporarily active combined sewer overflow. During stormflow, a large contribution of fast event water is observed. At low flow conditions losing and gaining conditions occur in parallel. However, when catchment's moisture conditions are high, an ephemeral source from clay shale-graywacke dominated forested sites becomes active. The study reveals that the collection of detailed distributed hydrometric data combined with isotopic tracers, provides fundamental information on the complex catchment behavior, which can finally be utilized for conceptualizing water fluxes at a small catchment scale.
\end{abstract}


Keywords: groundwater-surface water interaction; groundwater table dynamics; multi-method approach; flow duration curve; lag-to-peak time; hydrograph separation; slug test; small catchment behavior

\section{Introduction}

Understanding the movement of biochemicals, such as nitrogen compounds or pesticides, in agricultural dominated catchments, knowledge about water pathways, and the interplay between surface and groundwater sources is essential. Because nearly all European river systems were already substantially modified by humans before river ecology research developed [1,2], the complex character of developed agricultural dominated catchment is often disregarded and established research approaches often failed to fully capture agro-ecosystem functioning at multiple scales. To account for catchment heterogeneity a multi-method approach was conducted to study the behavior of water fluxes and the interplay between groundwater and surface water in a small, agriculturally dominated catchment in mid Germany.

While multi-method approaches have historically been less common, they can overcome the large uncertainties that are attributed to single method applications and provide additional and more robust information for example in groundwater-surface water interactions [3-5] to obtain unequivocal results [6]. Moreover, by combining methods in different compartments of the hydrological cycle or different scales within the catchment (plot-, reach-scale) long time series are not necessarily needed to understand catchment reaction or the contribution of runoff components during varying saturation conditions (floods or low flow) in small and meso-scale catchments [7-10]. The range of available techniques to study water fluxes, such as runoff generation processes or groundwater-surface water interactions, are broad and include hydrometric based approaches, chemical tracers, modeling, and stable isotope applications, amongst others. These spatiotemporal different methods are either applied within the aquifer, in the surface water, or in the transition zone itself [11]. Hydrometric data such as rainfall, discharge, and groundwater head level, are utilized to specify the timing of the hydrological response, isotopic data can define the relative contributions of pre-event or event water to the overall catchment response [6,12], and hydrochemicals help to elucidate water flow paths [13]. Each method has its own strength and weaknesses e.g., regarding costs or the spatiotemporal scale at which it can be applied and the information it yields [14]. Nevertheless, detailed distributed information is a key to meaningfully characterize and conceptualize catchment internal processes [10] to furthermore improve agro-hydrological model simulations, since simulations of catchment functioning are only approximations [15].

The objective of this study, therefore, is to identify major runoff components and to characterize the interplay of groundwater-surface water sources on different spatiotemporal scales to conceptualize water fluxes in a small catchment. The specific questions that will be addressed are as follows:

1. Does streamflow respond equally to rainfall input throughout the whole stream reach and which runoff sources are contributing to stormflow?

2. Is the studied stream a gaining or losing system?

3. Do groundwater head levels and flow dynamics respond to variations in stream stage and is this flow behavior changing throughout the year? 


\section{Materials and Methods}

\subsection{Study Area}

The research is carried out in the Vollnkirchener Bach catchment, which is part of the Schwingbach main catchment. The Schwingbach and its tributary the Vollnkirchner Bach are low-mountainous creeks located in Hüttenberg $\left(50^{\circ} 30^{\prime} 0^{\prime \prime} \mathrm{N}, 8^{\circ} 37^{\prime} 0^{\prime \prime}\right.$ E, Hesse, Germany) (Figure 1A) in an anthropogenic-influenced landscape (altered physical structure of stream system: channeled stream reaches, pipes, combined sewer overflow, drainage systems, fishponds). Both creeks are part of the "Study landscape Schwingbachtal" [16] of the Justus Liebig University Giessen.

The Vollnkirchener Bach is about $4.7 \mathrm{~km}$ in length and drains a $3.7 \mathrm{~km}^{2}$ catchment (Figure 1). Land use is dominated by forest sites (48\%) in the eastern and southern regions and arable land (35\%), concentrated in the western region (Figure 1B). Grassland sites (9\%) are mainly distributed along the stream. Elevation ranges from $235 \mathrm{~m}$ a.s.1 in the northern parts to $351 \mathrm{~m}$ a.s.1 in the southern areas (Figure 1B). Soils are forested Cambisols in the eastern and southwestern parts as well as agricultural Stagnosols with thick loess layers (Stagnic Luvisols) in the western catchment areas. Gleysols can be found predominantly under grassland sites along the creek (Figure 1C). The geology is comprised of limestone, sandstone and quartzite in the headwater area-providing aquifers with large storage capacities [17,18] — passing into graywacke zones with siliceous shales in the central and further into clay shale in the north of the catchment, which can serve as aquicludes [18] (Figure 1D). At agricultural sites in the northwest loess covers Paleozoic bedrocks. Streambeds consist of loamy deposits over sand covered by some larger rock debris [19]. In the downstream section, the streambed and banks are partly reinforced by armor stones.

The climate is classified as temperate with a mean annual temperature of $8.2{ }^{\circ} \mathrm{C}$ and an annual precipitation sum of $633 \mathrm{~mm}$ (for the hydrological year 01.11.2012-31.10.2013) measured at the climate station at the catchment outlet. The year 2012-2013 was an average hydrological year. For comparison the climate station Giessen/Wettenberg $(25 \mathrm{~km} \cdot \mathrm{N}$ of the catchment) operated by the German Meteorological Service [20] records a mean annual temperature of $9.6{ }^{\circ} \mathrm{C}$ and a mean annual precipitation sum of $666 \pm 103 \mathrm{~mm}(1980-2010)$.

\subsection{Monitoring Network}

The instrumentation in the Schwingbach main catchment consists of two climate stations, four stream gauges ( $\mathrm{V}$-weir, RBC-flumes), nine precipitation collectors, eight tipping bucket rain gauges, and 22 piezometers.

Particularly, the Vollnkirchener Bach catchment is equipped with an automated weather station (Campbell Scientific Inc., AQ5, UK) at the catchment outlet (site 13) including a CR1000 data logger collecting data on atmospheric boundary conditions (air temperature at $2 \mathrm{~m}$ height, wind speed and direction, relative humidity, solar radiation). Since tipping bucket rainfall data are known to be imprecise in terms of rainfall depth and intensity peaks [21], it is recommended to correct the measured data [22] Therefore, precipitation data collected at the climate station within the catchment are corrected with an optimized regression model provided by the World Meteorological Organization (WMO) [23]. 
Figure 1. The maps show (A) the location of the Vollnkirchener Bach catchment near Hüttenberg in Germany; (B) the land use and major structural elements in the catchment (photos); (C) soils; and (D) geology. (Sources: soil map: HLUG [24], elevation map: HVBG [25]. Soil classes are mapped according to the World Reference Base for Soil Resources [26]). The photos depict (a) an ephemeral tributary; (b) a small perennial tributary; (c) a combined sewer overflow; (d) a channeled tributary; (e) a wetland; (f) an artificial pond; and (g) fishponds.

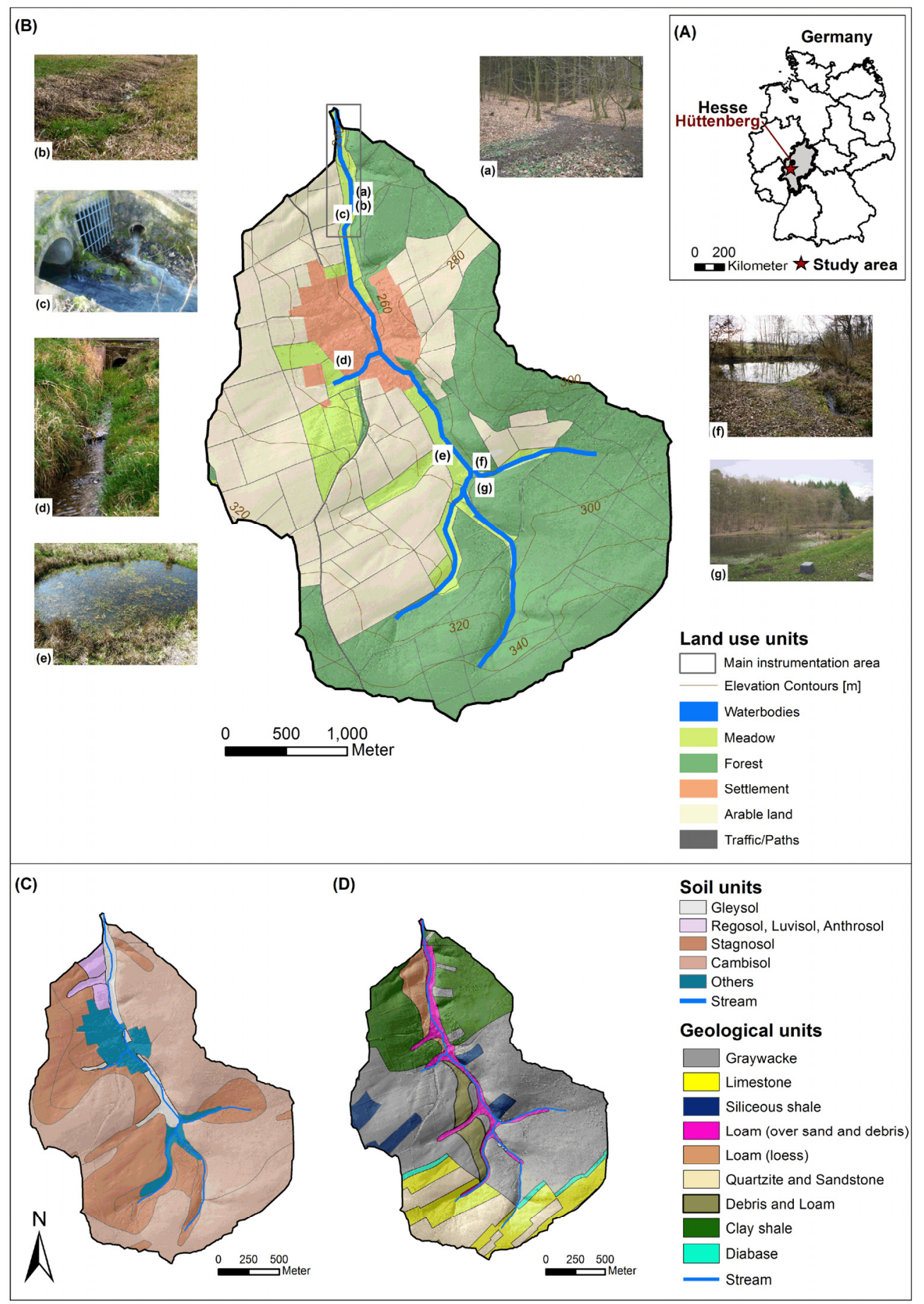


Two stream gauges are installed with trapezium shaped RBC-flumes (maximum peak flow $114 \mathrm{~L} \cdot \mathrm{s}^{-1}$, Eijkelkamp Agrisearch Equipment, Giesbeek, NL) at the upper (site 18) and lower course of the Vollnkirchener Bach (site 13) (Figure 2). Flumes are hydraulic structures with a well-known stage-discharge relationship for measuring streamflow, especially in small streambeds [27,28]. Both RBC-flumes are equipped with Mini-Divers ${ }^{\circledR}$ (Eigenbrodt Inc. and Co. KG, Königsmoor, Germany) for automatically recording water levels and deriving continuous discharge data through the given stage-discharge relationship of the flumes [27]. A combined sewer overflow (site 38) is located $\sim 40 \mathrm{~m}$ downstream of the upper RBC-flume contributing to streamflow at the Vollnkirchener Bach (Figures 1C and 2). The combined sewer overflow system captures Vollnkirchen Village's rainwater and wastewater, which is subsequently drained into the Vollnkirchener Bach.

Figure 2. Monitoring network and land use in the main instrumentation area (see Figure 1B).

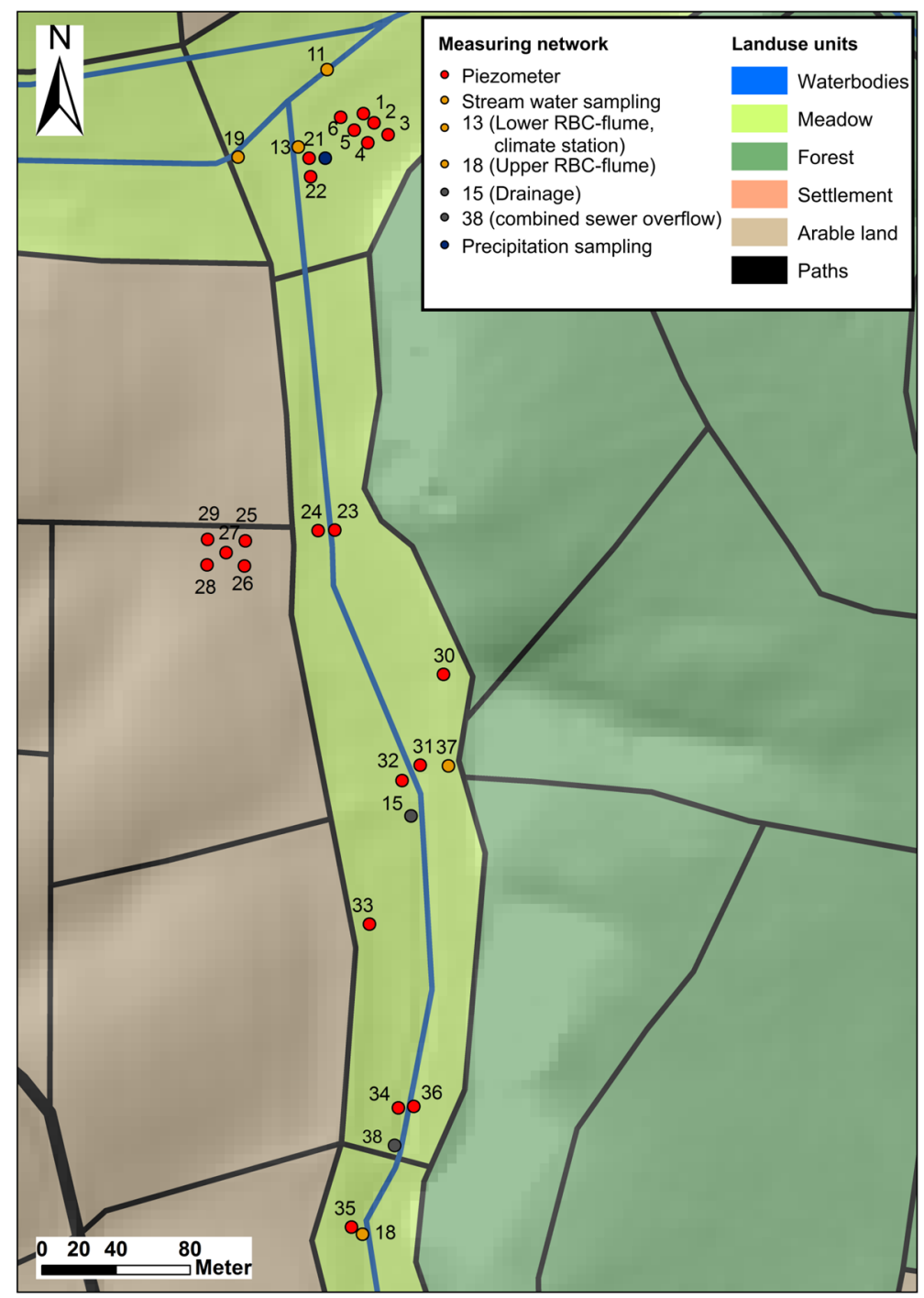

For hydrograph separation, stream water is sampled at the outlet of the Vollnkirchener Bach near to the lower RBC-flume utilizing an automatic water sampler (ISCO, Teledyne Technologies Inc., Lincoln, NE, USA). Stream water samples are taken at different intervals with higher temporal resolution at the beginning of an event ( $4 \times 15 \mathrm{~min}, 10 \times 30 \mathrm{~min}, 5 \times 60 \mathrm{~min}, 4 \times 240 \mathrm{~min}$ ). One bulk rainfall sample is taken for the whole event. 
For monitoring the level of shallow groundwater, 22 piezometers are located between the conjunction of the Schwingbach with the Vollnkirchener Bach and the upper RBC-flume of the Vollnkirchener Bach (Figure 2). Table 1 provides general information on the piezometers. Five piezometers are located on an arable field on the western site of the Vollnkirchener Bach, eight in the meadow near the conjunction of the creeks, and the remaining nine are distributed along the creek (Figure 2, Table 1). Piezometers are made from perforated PVC tubes and installed underfloor, except piezometer \#24. They are sealed with bentonite clay at the upper part of the tube to prevent contamination by surface water. Most of the piezometers are either equipped with combined water level/temperature loggers (Odyssey Data Flow System, Christchurch, New Zealand) or Mini-Diver ${ }^{\circledR}$ water level loggers (Eigenbrodt Inc. and Co. KG, Koenigsmoor, Germany) for automatically recording groundwater head level. Accuracy of Mini-Diver ${ }^{\circledR}$ is $\pm 5 \mathrm{~mm}$ and for Odyssey data logger $\pm 1 \mathrm{~mm}$.

Table 1. General information on piezometers installed along the Vollnkirchener Bach.

\begin{tabular}{|c|c|c|c|c|c|}
\hline Piezometer & Location & $\begin{array}{c}\text { Land } \\
\text { Use }\end{array}$ & $\begin{array}{c}\text { Groundwater Level } \\
\text { Measurements }\end{array}$ & $\begin{array}{c}\text { Height } \\
\text { a.s.l. (m) }\end{array}$ & $\begin{array}{c}\text { Minimum Distance } \\
\text { to Stream (m) }\end{array}$ \\
\hline 1 & \multirow{8}{*}{$\begin{array}{l}\text { Outlet Vollnkirchener } \\
\text { Bach }\end{array}$} & \multirow{10}{*}{ Meadow } & \multirow{15}{*}{ Automatic + manual } & 234.2 & 38.3 \\
\hline 2 & & & & 234.2 & 43.4 \\
\hline 3 & & & & 234.2 & 50.4 \\
\hline 4 & & & & 234.4 & 39.1 \\
\hline 5 & & & & 234.2 & 32.4 \\
\hline 6 & & & & 234.3 & 25.8 \\
\hline 21 & & & & 234.9 & 6.7 \\
\hline 22 & & & & 235.1 & 6.5 \\
\hline 23 & Eastern stream-site & & & 238.9 & 0.8 \\
\hline 24 & $\begin{array}{l}\text { Towards } 23 \text {, western } \\
\text { stream-site }\end{array}$ & & & 238.6 & 5.2 \\
\hline 25 & \multirow{5}{*}{$\begin{array}{l}\text { Western } \\
\text { hillslope site }\end{array}$} & \multirow{5}{*}{$\begin{array}{l}\text { Arable } \\
\text { land }\end{array}$} & & 239.6 & 44.8 \\
\hline 26 & & & & 240.2 & 46.2 \\
\hline 27 & & & & 240.4 & 55.8 \\
\hline 28 & & & & 241.2 & 66.3 \\
\hline 29 & & & & 240.3 & 65.0 \\
\hline 30 & $\begin{array}{l}\text { Eastern stream-site, } \\
\text { close to forest }\end{array}$ & \multirow{7}{*}{ Meadow } & Manual & 240.5 & 34.8 \\
\hline 31 & $\begin{array}{l}\text { Beside point source, } \\
\text { eastern stream-site }\end{array}$ & & \multirow{2}{*}{ Automatic + manual } & 240.9 & 4.3 \\
\hline 32 & $\begin{array}{l}\text { Towards } 31 \text {, western } \\
\text { stream-site }\end{array}$ & & & 241.0 & 5.0 \\
\hline 33 & Western stream-site & & Manual & 243.9 & 30.2 \\
\hline 34 & Western stream-site & & \multirow{3}{*}{ Automatic + manual } & 245.1 & 4.0 \\
\hline 35 & $\begin{array}{l}\text { Beside upper } \\
\text { RBC-flume, western } \\
\text { stream-site }\end{array}$ & & & 247.1 & 6.9 \\
\hline 36 & Eastern stream-site & & & 245.0 & 1.0 \\
\hline
\end{tabular}


Measurements performed in the study area (i.e., automatic, manual, and lab measurements) are stored in a relational database with a web-based management interface [29]. The data management system is able to read data files from the various instruments directly and, moreover, to perform calibrations by calculating linear regressions between automatically recorded instrument data and manual measurements. Additional features such as plotting, exporting, or the use of collaborative tools like assignment of maintenance tasks and wikis are provided. Limited functionality is publicly available. The access to more datasets will be supplied along with publications.

\subsection{Hydrodynamic Methods and Data Analysis}

Various methods listed in Table 2 are used to study groundwater-surface water interactions and streamflow generation processes in the Vollnkirchener Bach catchment.

\subsubsection{Streamflow Dynamics}

Flow Duration Curve Analysis

An essential information in catchment hydrology is the understanding of how much water is flowing down a stream, and further, how representative a certain flow is [30]. Therefore, flow frequency of discharge (flow duration curve) is analyzed to characterize the occurrence of a certain discharge (Table 2). For the flow duration curve analysis, runoff data with a 5 min resolution is utilized for calculations. Discharge is divided into 19 classes, each class including not more than $10 \%$ of recorded values. Relative and cumulative frequencies are calculated for each class. Finally, the flow duration curve is plotted with the percentage cumulative frequency on the x-axis and the mid-point of the class interval on the y-axis [30].

Table 2. Overview of applied surface water and groundwater measuring methods.

\begin{tabular}{|c|c|c|}
\hline Method & Aim & Location/Sites \\
\hline Flow duration curve & $\begin{array}{l}\text { Characterize the frequency of } \\
\text { occurrence of a certain discharge }\end{array}$ & 13,18 \\
\hline Lag-to-peak time & $\begin{array}{l}\text { Define catchment response } \\
\text { time to rainfall events }\end{array}$ & $\begin{array}{l}13,18, \text { combined } \\
\text { sewer overflow }\end{array}$ \\
\hline Hydrograph separation & $\begin{array}{l}\text { Determine contribution of } \\
\text { event/pre-event water to stormflow event }\end{array}$ & 13 \\
\hline $\begin{array}{l}\text { Incremental } \\
\text { stream gauging }\end{array}$ & $\begin{array}{l}\text { Detect gaining/losing reaches } \\
\text { along the Vollnkirchener Bach }\end{array}$ & $\begin{array}{l}12 \text { sampling points } \\
\text { along the creek }\end{array}$ \\
\hline $\begin{array}{l}\text { Groundwater } \\
\text { flow direction }\end{array}$ & $\begin{array}{l}\text { Define groundwater flux dynamics } \\
\text { under different saturation conditions }\end{array}$ & All piezometers \\
\hline Slug tests & $\begin{array}{l}\text { Estimate saturated hydraulic } \\
\text { conductivity of aquifer material }\end{array}$ & $\begin{array}{l}\text { Piezometers: } 1-6,21-24, \\
31,32,34,36\end{array}$ \\
\hline $\begin{array}{l}\text { Correlation of } \\
\text { groundwater head } \\
\text { level response }\end{array}$ & $\begin{array}{l}\text { Identify groundwater } \\
\text { relationships and patterns }\end{array}$ & $\begin{array}{l}\text { All automatically } \\
\text { measured piezometers }\end{array}$ \\
\hline $\begin{array}{l}\text { Correlation of } \\
\text { groundwater head } \\
\text { levels } v s . \text { discharge }\end{array}$ & $\begin{array}{l}\text { Characterize groundwater } \\
\text { response to discharge }\end{array}$ & $\begin{array}{l}\text { All automatically measured } \\
\text { piezometers vs. } 13,18\end{array}$ \\
\hline
\end{tabular}


Lag-to-Peak Times and Rainfall-Runoff Behavior

We apply the lag-to-peak time (ltp) to analyze response times of the rainfall-runoff processes (Table 2). Several definitions are available for the calculation of lag-to-peak time. We follow two of the most widely used definitions: (1) time interval between the beginning of rainfall and the occurrence of peak streamflow $\left(\operatorname{ltp}_{1}\right)$; (2) time lag between the centroid of effective rainfall and the occurrence of peak streamflow (1tp2) [31]. Lag-times are determined for stream response at both RBC-flumes (sites 13 and 18, Figure 2) and additionally, for the maximum flow contribution of the combined sewer overflow (Figure 1C). With the exception of combined sewer overflow-induced runoff events, single peak events are examined. The following variables are calculated to assess initial conditions and to characterize each rainfall-runoff event: rainfall duration $(\mathrm{h})$, rainfall sum $(\mathrm{mm})$, rainfall depth $\left(\mathrm{mm} \cdot \mathrm{h}^{-1}\right)$, antecedent precipitation index (AP) defined as the rainfall amount during the 3, 5, and 14 days prior to the storm event [32], discharge prior to the event $\mathrm{Q}_{0}\left(\mathrm{~L} \cdot \mathrm{s}^{-1}\right)$, maximum discharge $\left(\mathrm{Q}_{\max }\right)\left(\mathrm{L} \cdot \mathrm{s}^{-1}\right)$, ratio of maximum discharge to discharge prior to the event $\left(\mathrm{Q}_{\max } / \mathrm{Q}_{\mathrm{o}}\right)[-]$, $1 \mathrm{tp}_{1}$ and $\mathrm{ltp}_{2}(\mathrm{~min})$. Rainfall and runoff data with a $5 \mathrm{~min}$ resolution is utilized for calculations. Events are analyzed if runoff exceeded $15 \mathrm{~L} \cdot \mathrm{s}^{-1}$ for one of the studied gauging stations. Taking event characteristics and lag-times as a basis, differences in stream response between the up- and downstream gauging stations $(18,13)$ are considered and different types of runoff events were compared.

Hydrograph Separation

Determining the contribution of event (rainfall) or pre-event water (groundwater) to a certain stormflow event, hydrograph separation utilizing stable water isotopes as tracers is conducted (Table 2). Stable isotopic tracers are used because rain water often has a different isotopic composition than pre-event water that is already existing in the catchment such as groundwater $[11,12,33]$. In the present study, a standard two-component mixing model based on mass balances for tracer fluxes and water is applied [9,34,35]:

$$
\begin{gathered}
Q_{s}=Q_{1}+Q_{2} \\
Q_{s} C_{s}=Q_{1} C_{1}+Q_{2} C_{2}
\end{gathered}
$$

where $Q_{s}$ is streamflow, $Q_{1}$ and $Q_{2}$ are contributions from event and pre-event water; $C_{s}, C_{1}$, and $C_{2}$ are $\delta$-values in streamflow, event and pre-event water, respectively. The relative contribution of event and pre-event water can be calculated at any given time from Equations (3) and (4), if the total streamflow $Q_{s}$ and the $\delta$-values in streamflow, event and pre-event water are known:

$$
\begin{gathered}
Q_{2}=\frac{C_{s}-C_{1}}{C_{2}-C_{1}} Q_{s} \\
Q_{1}=Q_{s}-Q_{2}
\end{gathered}
$$

Precipitation and stream water samples are analyzed for their stable water isotopic composition at the Institute for Landscape Ecology and Resources Management (ILR, JLU Giessen, DE) according to the IAEA standard procedure [36] using Off-Axis Integrated Cavity Output Spectroscopy (OA-ICOS, DLT-100 Liquid Water Isotope Analyzer, Los Gatos Research Inc., Mountain View, CA, USA). Isotopic ratios are reported in per mil (\%) relative to an international acknowledged standard, i.e., the Vienna 
Standard Mean Ocean Water (VSMOW) [37]. Accuracy of analyses are $0.6 \%$ for $\delta^{2} \mathrm{H}$ and $0.2 \%$ for $\delta^{18} \mathrm{O}[38]$.

\section{Incremental Stream Gauging}

Incremental flow gauging uses the difference in stream discharge at two points along a reach in order to identify net water gains or losses along the creek [11,39,40]. Mainly three types of stream-groundwater interactions are distinguished: streams gain water from groundwater exfiltration (gaining stream system), they lose water to the groundwater body by infiltration through the streambed (losing stream system), or both gaining or losing conditions are occurring in parallel [41].

Stream gauging has to be conducted under baseflow conditions allowing the net groundwater discharge or recharge to be calculated [4,11]. Incremental streamflow is measured on 24 April 2013 at low flow conditions via salt dilution measurements from the outlet of the Vollnkirchener Bach to the upstream boundary in $200 \mathrm{~m}$ steps, resulting in 12 sampling points (Table 2). Salt dilution gauging can be precise to $\pm 5 \%$ [42,43]. For details on the salt dilution method, the reader is referred to $[42,44,45]$. No precipitation had been recorded for eight days prior to the measurements. On this basis, one can assume that all measured increases in stream discharge along the monitored reach are the result of groundwater discharge, tributary contributions, or combined sewer overflow inputs [11,39]. Gains or losses are determined by subtracting the discharge of the successive sampling points from each other.

\subsubsection{Groundwater Dynamics}

\section{Groundwater Flow Direction Analyses}

Studying the interplay of surface and groundwater, the analysis of regional groundwater flow in relation to topographical characteristics and surface water bodies is essential in order to determine what type of interaction is occurring in the study region (Table 2). Thereby, water-table maps provide information on the elevation of the groundwater table and the direction of groundwater flow. Water-table contour lines indicate whether a stream reach is gaining or losing at a specific time [11,41]. However, groundwater flow directions can change within short periods caused by stormflow events, transpiration of water by streamside vegetation or focused recharge near the streambank [41].

In this study groundwater flow direction maps are calculated on the basis of automatically recorded groundwater level data (15 min resolution) calibrated through manually measured groundwater head via electric contact gauge. For piezometers 30 and 33 only manually measurements are available. To interpolate the irregular groundwater data between the piezometers throughout the studied stream reach to a regular grid, the natural neighbor method is applied [46] using Matplotlib.

\section{Aquifer Hydraulic Conductivity}

Hydraulic conductivity provides essential information on water flux rates in the unsaturated and saturated zone, strongly affecting water infiltration, surface runoff, and the spreading rate of possible contaminations such as pesticides or fertilizer in the groundwater body [47]. Obtaining a rapid overview of the hydraulic properties of the shallow aquifer in the study region, rising head slug tests are conducted for 14 piezometers along the downstream section of the Vollnkirchener Bach (Table 2). Slug tests 
constitute a powerful, simple, and low-cost in situ approach to define spatial variations in the hydraulic conductivity of an aquifer with inexpensive equipment [11,47-49]. For details on performing slug tests the reader is referred to $[48,49]$. Saturated hydraulic conductivities $\left(K_{\text {sat }}\right)$ are calculated for each of the 14 investigated piezometers applying the Hvorslev method [50]. The obtained values are furthermore utilized for interpolating hydraulic conductivities between the piezometers via inverse distance weighting.

Groundwater Head Level Correlations and Piezometric Stream Stage Response

Similar to references [15,51], correlation analysis on a daily basis between the 20 piezometers measured automatically are performed for the hydrological year 2012-2013, to further characterize the groundwater head level relations. Additional correlation analyses between the discharge at sites 13 and 18 and the groundwater head levels at each piezometer are calculated to investigate groundwater level response to streamflow.

\section{Results}

\subsection{Streamflow Dynamics}

The observed discharge for the hydrological year 2012-2013 has a significant seasonal periodicity characterized by higher discharge from December to April and a low flow season during July until November (mean monthly discharge at lower RBC-flume: 1.6-5.9 L $\cdot \mathrm{s}^{-1}$ ). Significant snowmelt peaks were observed during December 2012 and February 2013. May 2013 was an exceptional wet month with discharge $>114 \mathrm{~L} \cdot \mathrm{s}^{-1}$ at the lower discharge gauge and a monthly maximum of $110 \mathrm{~L} \cdot \mathrm{s}^{-1}$ at the upper gauge. The absolute maximum discharge for the water year 2012-2013 at both sites was measured at 26 May 2013 (Figure 3). The observed discharge responded to nearly all precipitation events immediately, which was true for both sites (Figure 3). However, moderate precipitation sums during July to October 2013 were in no relation with large discharges. Moreover, a daily precipitation sum of $33.6 \mathrm{~mm} \cdot \mathrm{d}^{-1}$ recorded on 5 October 2013 did only cause a small runoff peak of $20-21 \mathrm{~L} \cdot \mathrm{s}^{-1}$ at both sites, while a similar rainfall event $\left(27.7 \mathrm{~mm} \cdot \mathrm{d}^{-1}\right)$ on 26 May 2013 resulted in discharge $>110 \mathrm{~L} \cdot \mathrm{s}^{-1}$. Furthermore, runoff recorded at the downstream RBC-flume (13) exceeded the measured values at the upstream RBC-flume (18) mostly during stormflow events, whereby during baseflow or low flow, discharge at the upper flume showed higher values than at the lower flume (Figure 3, small inset with logarithmic scale).

\subsubsection{Flow Duration Curve Analyses}

We analyzed flow duration curves for the hydrological year 2012-2013 to get an overview on flow characteristics (occurrence of a certain discharge) of both discharge gauging stations at the Vollnkirchener Bach. Even though field event-based observations were partly different for both stations, flow duration behavior was almost similar (Figure 4). With a frequency of $10 \%$ discharge exceeds $35 \mathrm{~L} \cdot \mathrm{s}^{-1}$ and $50 \%$ of the discharge was $>7 \mathrm{~L} \cdot \mathrm{s}^{-1}$ at both sites. However, flows in discharge classes $<10 \mathrm{~L} \cdot \mathrm{s}^{-1}$ were less relevant in relation to the water volume flowing downstream, exemplary shown for gauging station 13 (Figure 4, insert). In contrast, streamflow $>35 \mathrm{~L} \cdot \mathrm{s}^{-1}$ was infrequent, but of high relevance by volume. Differences between the two flow duration curves of gauging stations 13 and 18 were as follows: 
during baseflow conditions $\left(<10 \mathrm{~L} \cdot \mathrm{s}^{-1}\right)$ discharge at the upper RBC-flume 18 exceeded the one at the lower flume by $4 \%-10 \%$. Whereas for discharge $>50 \mathrm{~L} \cdot \mathrm{s}^{-1}$, streamflow at the lower gauging station 13 surpassed the one at the upper site 18 by $0.3 \%-0.8 \%$.

\subsubsection{Lag- to-Peak Times and Rainfall-Runoff Behavior}

We identified four different hydrologic response types when calculating stream reaction times to rainfall input signals utilizing the lag-to-peak time concept (Figure 5, Table 3): Response type (I) higher discharge at the upper RBC-flume than at the lower RBC-flume; (II) lower discharge at the upper RBC-flume as compared to the lower RBC-flume; (III) equal discharge at both sites; and (IV) combined sewer overflow-induced discharge at the lower RBC-flume. Table 3 summarizes the conditions that caused the occurrence of the four different response types that were analyzed for the water year 2012-2013. For the most frequent rainfall-runoff behavior discharge at the lower RBC-flume exceeded the one measured at the upstream gauge, for three times it was vice versa (Figure 5A,B). Since differences in $\mathrm{Q}_{\max }$ between both measuring points were small $\left(0.6-5.5 \mathrm{~L} \cdot \mathrm{s}^{-1}\right)$, event types similar to Figures $5 \mathrm{~A}$ and $6 \mathrm{C}$ could not easily be distinguished.

Figure 3. Time series of daily precipitation $\left(\mathrm{mm} \cdot \mathrm{d}^{-1}\right)$ and discharge $\left(\mathrm{L} \cdot \mathrm{s}^{-1}\right)$ at the lower and upper RBC-flume $(13,18)$ for the water year 2012-2013. Small inset includes discharge plotted on a logarithmic scale.

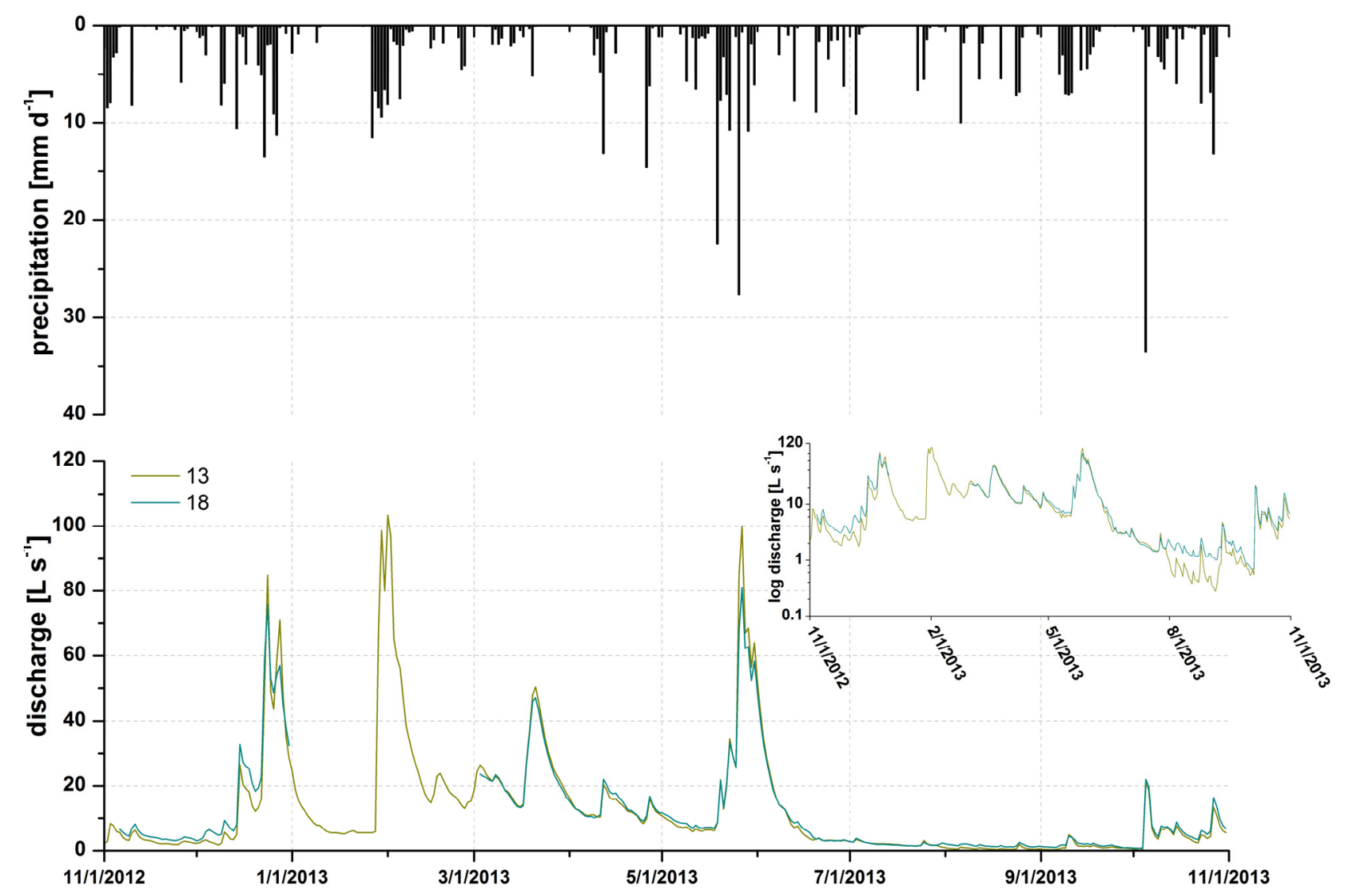


Figure 4. Flow duration curves for lower and upper RBC-flumes $(13,18)$ at the Vollnkirchener Bach (hydrological year 2012-2013). Insert exemplary shows classified cumulative discharge $\left(\mathrm{L} \cdot \mathrm{s}^{-1}\right)$ for lower RBC-flume.

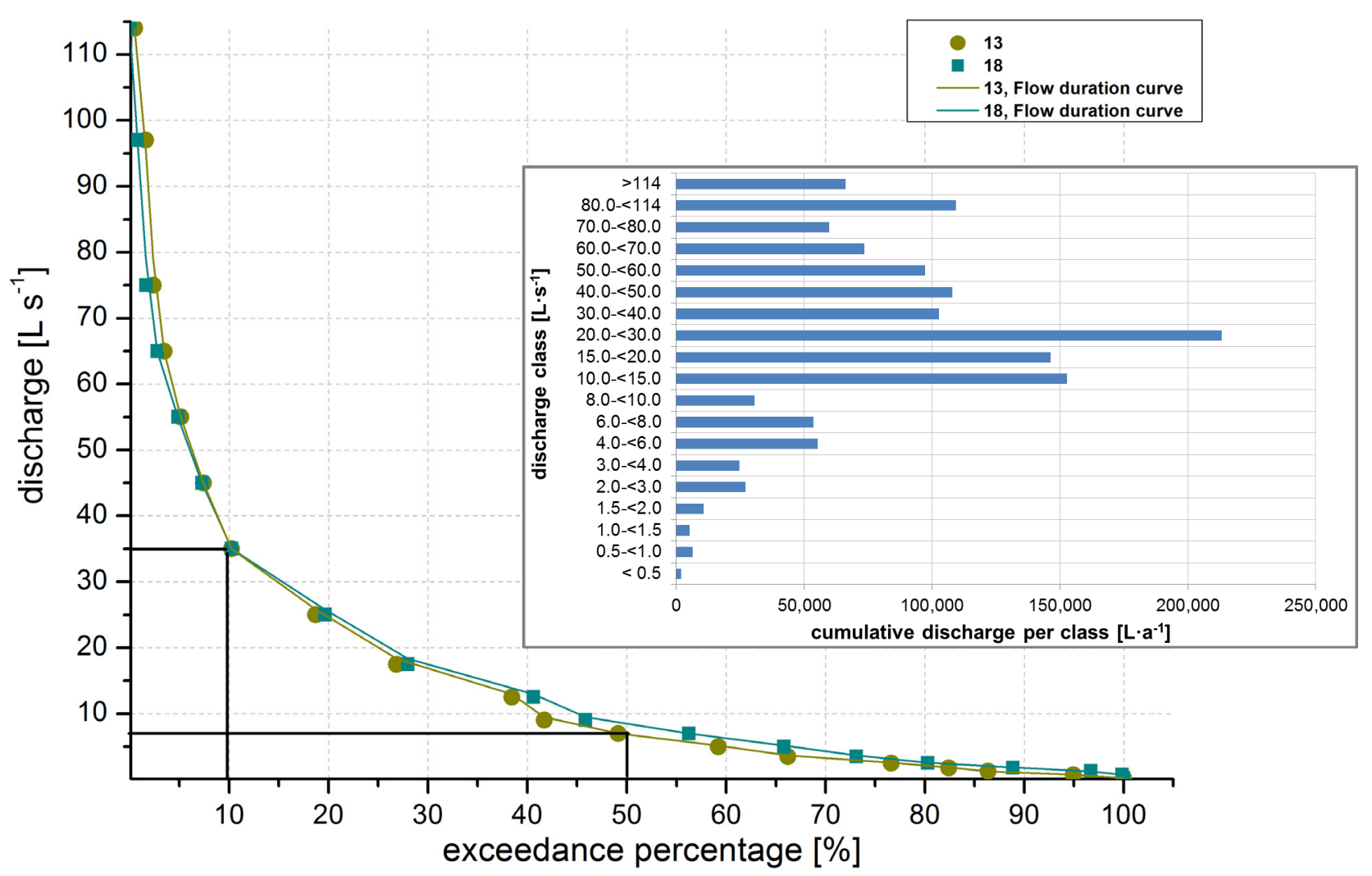

When peak flow at the upstream site was higher than at the downstream site (Figure 5A, response type I), ltp2's of $3 \mathrm{~h} 57 \mathrm{~min}-7 \mathrm{~h} 12 \mathrm{~min}$ were calculated for the upper RBC-flume and $3 \mathrm{~h} 27 \mathrm{~min}-7 \mathrm{~h} 37 \mathrm{~min}$ for the lower flume, respectively (Table 3). AP14d values were $<50 \mathrm{~mm}$ and rainfall amounts ranged between 5 and $11 \mathrm{~mm}$. For one out of the three detected events, hydrographs raised simultaneously at both sites (ltp $2=4 \mathrm{~h} 52 \mathrm{~min}$ ). For another, $\mathrm{Q}_{\max }$ was measured $37 \mathrm{~min}$ earlier downstream. For the third one, a difference in response times between both sites of $25 \mathrm{~min}$ was calculated.

For six out of 25 events, discharge at the lower RBC-flume was dominated by the activation of a combined sewer overflow (site 38) located $\sim 40$ m downstream of the upper flume (Figures 1B(c) and 2) leading to response type IV. Generally, shortest lag-times and with that quickflow were detected for these combined sewer overflow-dominated events. Rainfall intensities between 0.8 and $3.7 \mathrm{~mm} \cdot \mathrm{h}^{-1}$ and high $\mathrm{Q}_{\max } / \mathrm{Q}_{0}$ ratios characterized this type of events (Table 3). Due to the rapid and intense discharge reaction, the concept of $1_{1 t} 2$ was not consistently applicable for events generated by combined sewer overflow. Therefore, ltp $_{1}$ was additionally calculated. Figure 5D depicts a combined sewer overflow-affected runoff-event at 11 September, 2013 with $1 \operatorname{ltp}_{1}$ of only 50 min (ltp: $\left.27 \mathrm{~min}\right)$ and a maximum contribution of the combined sewer system of $>114 \mathrm{~L} \cdot \mathrm{s}^{-1}$. However, combined sewer overflow events were only apparent if $\mathrm{Q}_{0}$ was $<5 \mathrm{~L} \cdot \mathrm{s}^{-1}$. With increasing $\mathrm{Q}_{0}$ values and concurrently decreasing $\mathrm{Q}_{\max } / \mathrm{Q}_{0}$ ratios, combined sewer overflow-induced streamflow was superposed by higher flood waves flowing down the creek.

The most common streamflow reaction (type II) is shown in Figure 5B. At this event on 27 December 2012, a strong gain in downstream direction towards the catchment outlet occurred 
$\left(+23.5 \mathrm{~L} \cdot \mathrm{s}^{-1}\right)$. This type of event was observed when wet conditions (high AP values) predominate, i.e., in the winter season and during the rainy May 2013. Generally, a wide range of rainfall durations and rainfall amounts caused this type of event, which resulted in ltp2's between 2:17 and 12:37 h for site 13 and 1:32-12:47 $\mathrm{h}$ for site 18 , respectively (Table 3 ).

An almost equal and simultaneous hydrograph reaction at both discharge gauges characterizes response type III, exemplary shown for 11 April 2013 (Figure 5C). This peak flow reaction was generally initiated by long rainfall events with low rainfall intensities of $1.1-1.5 \mathrm{~mm} \cdot \mathrm{h}^{-1}$, resulting in likewise stretched lag-times (ltp $2=3 \mathrm{~h} 32 \mathrm{~min}-10 \mathrm{~h} 52 \mathrm{~min}$ at the lower RBC-flume, and $3 \mathrm{~h} 02 \mathrm{~min}-9 \mathrm{~h} 27 \mathrm{~min}$ at the upper RBC-flume).

Figure 5. Time series of precipitation $\left(\mathrm{L} \cdot \mathrm{s}^{-1}\right)$ and discharge $\left(\mathrm{L} \cdot \mathrm{s}^{-1}\right)$ depicted for four characteristic rainfall-runoff events including lag-to-peak times (inserted tables): (A) discharge at upper RBC-flume (18) > discharge at lower RBC-flume (13); (B) discharge at lower RBC-flume $>$ discharge at upper RBC-flume; $(\mathbf{C})$ almost equal discharge at both discharge gauging stations; and (D) combined sewer overflow-induced event.

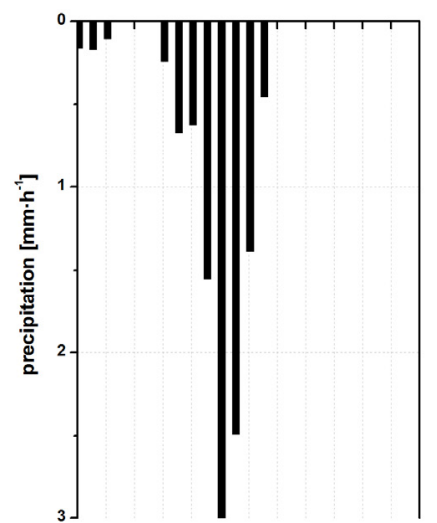

(A)

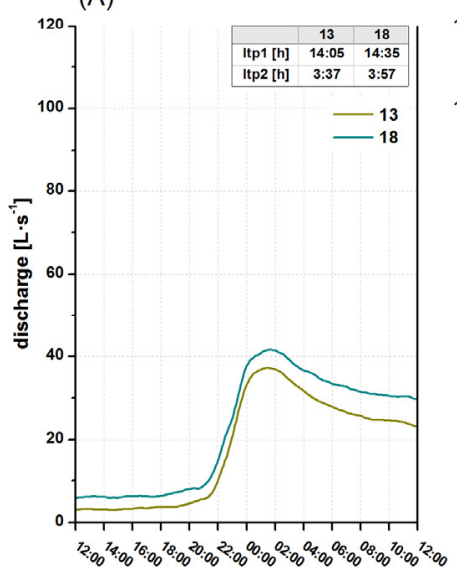

$12 / 14 / 12$

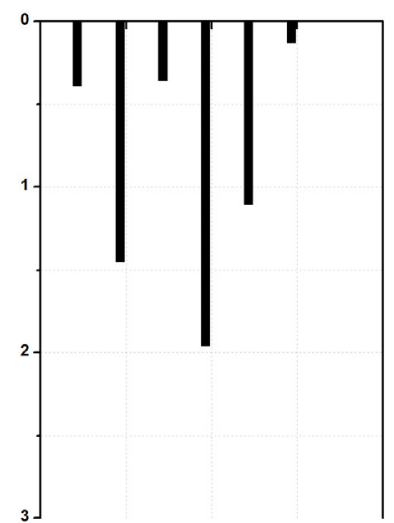

(B)

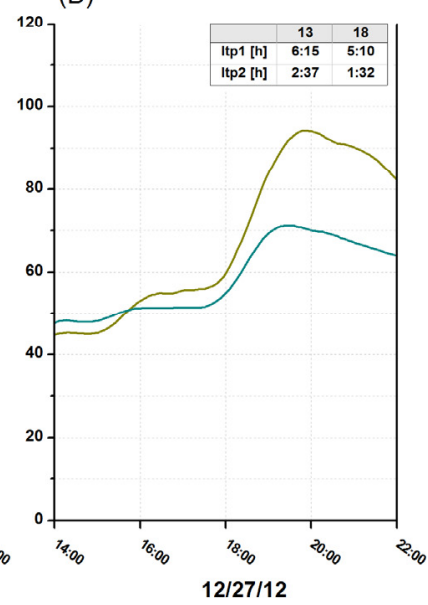

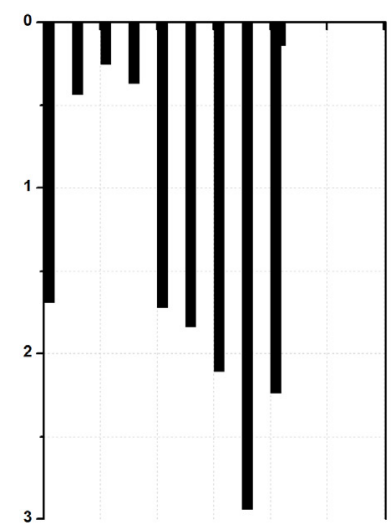

(C)

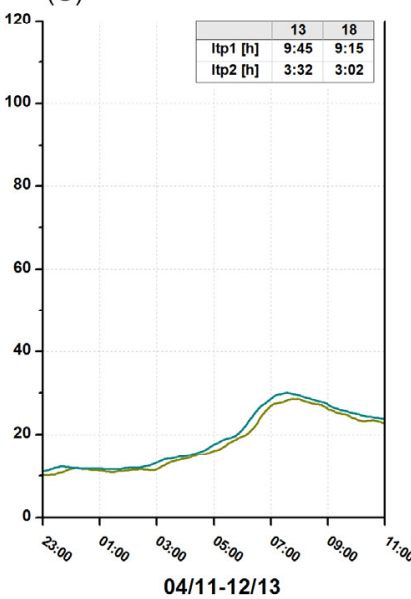

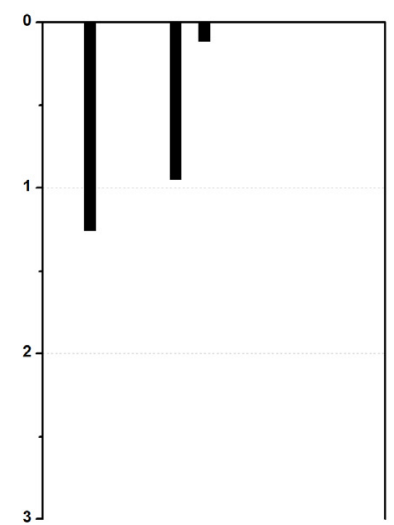

(D)

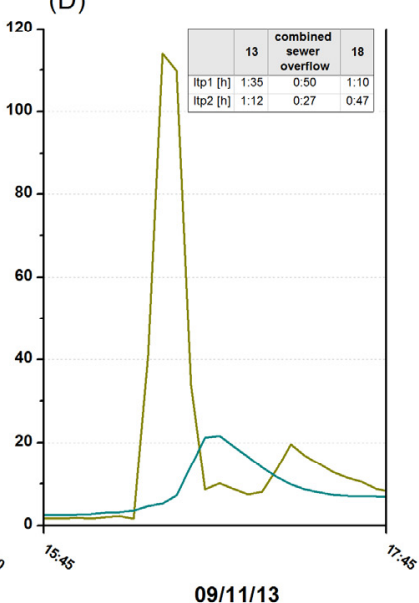


Table 3. Summary statistics for ltp-analyses of rainfall-induced runoff events.

\begin{tabular}{|c|c|c|c|c|c|c|c|c|c|c|c|c|c|c|c|c|c|c|c|}
\hline & \multicolumn{3}{|c|}{ Rainfall } & \multicolumn{3}{|c|}{$\mathbf{A P}(\mathbf{m m})$} & \multicolumn{7}{|c|}{ Discharge $\left(L \cdot \mathbf{s}^{-1}\right)$} & \multicolumn{3}{|c|}{$\operatorname{ltp}_{1}(\mathrm{~h})$} & \multicolumn{3}{|c|}{$\operatorname{ltp}_{2}(\mathrm{~h})$} \\
\hline & & & & & & & \multicolumn{2}{|c|}{$\mathrm{Q}_{0}$} & \multicolumn{3}{|c|}{$\mathrm{Q}_{\max }$} & \multicolumn{2}{|c|}{$\mathrm{Q}_{\max } / \mathrm{Q}_{0}$} & & & & & & \\
\hline & $\begin{array}{l}\text { Duration } \\
\text { (h) }\end{array}$ & $\begin{array}{l}\text { Total } \\
(\mathrm{mm})\end{array}$ & $\begin{array}{c}\text { Mean } \\
\left(\mathrm{mm} \cdot \mathrm{h}^{-1}\right)\end{array}$ & $3 \mathrm{~d}$ & $5 \mathrm{~d}$ & $14 \mathrm{~d}$ & 13 & 18 & 13 & 18 & $\begin{array}{c}\text { combined } \\
\text { sewer } \\
\text { overflow }\end{array}$ & 13 & 18 & 13 & 18 & $\begin{array}{c}\text { combined } \\
\text { sewer } \\
\text { overflow }\end{array}$ & 13 & 18 & $\begin{array}{c}\text { combined } \\
\text { sewer } \\
\text { overflow }\end{array}$ \\
\hline \multicolumn{20}{|c|}{ Event-type I $(\mathrm{N}=3)$} \\
\hline Min & $5: 15$ & 4.9 & 0.7 & 0.0 & 9.5 & 19.3 & 3.3 & 5.2 & 18.4 & 20.5 & & 4.2 & 3.4 & $7: 25$ & $7: 25$ & & $3: 27$ & $3: 57$ & \\
\hline \multirow{2}{*}{ Max } & $13: 40$ & 11.3 & 1.7 & 3.9 & 14.0 & 49.0 & 4.4 & 6.2 & 38.6 & 42.0 & & 11.6 & 8.0 & 14:05 & $14: 3$ & & $7: 37$ & $7: 12$ & \\
\hline & & & & & & & & & & & & & & & 5 & & & & \\
\hline \multicolumn{20}{|c|}{ Event-type II (N = 12) } \\
\hline \multirow{3}{*}{$\begin{array}{l}\text { Min } \\
\text { Max }\end{array}$} & $1: 30$ & 1.5 & 0.8 & 1.5 & 2.0 & 11.5 & 12.7 & 11.9 & 62.2 & 59.0 & & 1.2 & 1.1 & $2: 40$ & $2: 20$ & $7: 20$ & $2: 17$ & $1: 32$ & $5: 42$ \\
\hline & $25: 30$ & 28.2 & 2.2 & 27.7 & 42.9 & 95.6 & 83.9 & 73.4 & 140.5 & 110.1 & & 10.0 & 7.2 & $25: 30$ & $25: 4$ & & $12: 37$ & $12: 4$ & \\
\hline & & & & & & & & & & & & & & & 0 & & & 7 & \\
\hline \multicolumn{20}{|c|}{ Event-type III $(\mathrm{N}=4)$} \\
\hline \multirow{3}{*}{$\begin{array}{l}\text { Min } \\
\text { Max }\end{array}$} & $7: 45$ & 9.3 & 1.1 & 0.0 & 0.0 & 0.6 & 0.6 & 0.8 & 18.1 & 18.7 & & 2.3 & 2.1 & $8: 30$ & 8:40 & & $3: 32$ & 3:02 & \\
\hline & $26: 15$ & 35.6 & 1.5 & 31.0 & 31.2 & 49.4 & 11.5 & 12.4 & 45.7 & 46.5 & & 74.3 & 55.4 & $18: 20$ & $18: 2$ & & $10: 52$ & $9: 27$ & \\
\hline & & & & & & & & & & & & & & & 0 & & & & \\
\hline \multicolumn{20}{|c|}{ Event-type IV $(\mathrm{N}=6)$} \\
\hline \multirow{2}{*}{$\begin{array}{l}\text { Min } \\
\text { Max }\end{array}$} & 1:05 & 2.3 & 0.8 & 0.0 & 0.0 & 6.8 & 0.1 & 0.8 & 5.1 & 7.2 & 34.5 & 4.8 & 3.6 & $1: 00$ & $0: 40$ & $0: 30$ & $0: 42$ & $0: 12$ & $0: 27$ \\
\hline & $9: 20$ & 29.1 & 3.7 & 16.9 & 22.3 & 23.2 & 4.5 & 5.9 & 21.8 & 21.6 & $>114.0$ & 53.8 & 15.9 & $3: 30$ & 3:00 & $2: 50$ & $1: 30$ & $0: 55$ & $0: 35$ \\
\hline
\end{tabular}


Comparing factors that influence the hydrological responses and their magnitudes in the catchment, only weak correlations between $\mathrm{AP}$ values and $\mathrm{Q}_{0}$ were found $\left(\mathrm{R}^{2}=0.4,0.5,0.4\right.$ for the lower RBC-flume; $\mathrm{R}^{2}=0.4,0.4,0.4$ for the upper RBC-flume with AP3d, 5d, 14d) as well as minor linear relationships between total rainfall amount and lag-times (for the lower RBC-flume: $\mathrm{R}^{2}=0.5$ (ltp1), 0.3 (ltp2); for the upper RBC-flume $\mathrm{R}^{2}=0.4$ ( $\left.\left(\operatorname{ltp}_{1}\right), 0.4\left(\operatorname{ltp}_{2}\right)\right)$. Obviously, rainfall durations correlated well with catchment response times $\left(\mathrm{R}^{2}=0.9\left(\operatorname{ltp}_{1}\right), 0.6\left(\operatorname{ltp}_{2}\right)\right.$ for the downstream site; $\mathrm{R}^{2}=0.9\left(\operatorname{ltp}_{1}\right)$, 0.6 ( $\left(\mathrm{tp}_{2}\right)$ for the upstream site), showing longer lag-times with increasing rainfall durations. However, we found no relationship between total rainfall amount and $\mathrm{Qmax}_{\max }$ for both sites, as well as no correlation between AP and $\mathrm{Q}_{\max }$ or AP and lag-times. Nevertheless, during rainfall-runoff events gaining conditions towards the catchment outlet with fast precipitation-induced streamflow reactions (short lag-times) were observed more frequently. Flood waves generally traveled downstream with $0.1-1.0 \mathrm{~m} \cdot \mathrm{s}^{-1}$. Especially when the combined sewer overflow became active, $\mathrm{Q}_{\max }$ occurred earlier downstream than upstream.

\subsubsection{Hydrograph Separation}

To determine the absolute maximum of event water contribution to streamflow, the highest peak flow event recorded in the water year 2012-2013 was chosen for two-component hydrograph calculation. Stable water isotope tracers were utilized for hydrograph separation. Concentrations of event water $\delta^{2} \mathrm{H}$ were determined from Equations (3) and (4) and pre-event $\delta^{2} \mathrm{H}$ water was taken as baseflow prior to the event. Between 26 and 27 May 2013, $28 \mathrm{~mm}$ (Figure 6A) of isotopically distinct rain precipitated on the Vollnkirchener catchment causing the absolute maximum discharge for the water year 2012-2013 (Figure 6A), resulting in response type II. The antecedent wetness AP5d was $28.8 \mathrm{~mm}$.

As can be seen from Figure $6 \mathrm{~A}, \mathrm{~B}$, the larger the contribution of the isotopically light bulk rainfall (dashed blue line: $-76.7 \%$, note the stable isotopic concentration in precipitation throughout the event), the lighter became the isotopic signature in stream water (dotted dark blue line). This reaction pattern can be observed until stream water isotopic signatures levelled out with a stable difference of $+6.7 \%$ compared to precipitation. Simultaneously, the calculated event water contribution is around $70 \mathrm{~L} \cdot \mathrm{s}^{-1}$ at the lower RBC-flume (Figure 6A). Towards the end of the event, stream water isotopic signatures increased again towards groundwater $\delta^{2} \mathrm{H}$ values (dashed green line: $-58.9 \%$ ). Groundwater responded as quickly as streamflow with increasing head levels, nearly reaching the land surface (Figure 6C).

\subsubsection{Incremental Stream Gauging}

Flow gauging at 12 locations from the outlet of the Vollnkirchener Bach upstream to the headwater identified which reaches were gaining or losing water during low flow conditions (Figure 7A). Assuming an error of $\pm 5 \%$ for salt dilution measurements, insignificant differences for losing and gaining stream reaches where $-0.3-1.2 \mathrm{~L} \cdot \mathrm{s}^{-1}$ and $-0.2-0.8 \mathrm{~L} \cdot \mathrm{s}^{-1}$, respectively. In general, the flow increased from the catchment headwater downstream as tributaries joined the main watercourse (Figures 1B and 7B). From 0-0.9 km stream length, growing subcatchment size generated increasing streamflow (Figure 7B) due to the contribution of a wetland, an artifical pond, and fishponds (Figure 1B(e-g)). At a stream length of $1.4 \mathrm{~km}$ flow decreased by $-0.2 \mathrm{~L} \cdot \mathrm{s}^{-1}$, although subcatchment area slightly enlarged $\left(+0.1 \mathrm{~km}^{2}\right)$ (Figure 7B) causing losing conditions (Figure 7A). Downstream, a minor channeled tributary joins the main creek leading to net water gains of $+2.6 \mathrm{~L} \cdot \mathrm{s}^{-1}$. However, along the last stream reach insignificantly 
losing or indifferent conditions were dominating streamflow (Figure 7A). The only gaining reach could be explained by a small perennial tributary from the eastern forest site (Figure 1B), which is significantly feeding the stream. Due to the mainly losing or indifferent character of the creek in the downstream section, other observed contributors such as a drainage system or wet spots on the western stream-site seemed to be negligible $(<5 \%)$ during baseflow. Therefore, discharge at the downstream section (stream length: $3.2-4.7 \mathrm{~km})$ remained almost constant $\left(11.4-13.0 \mathrm{~L} \cdot \mathrm{s}^{-1}\right)$, even though the catchment area increases (Figure 7B). Flow finally peaked $\left(13.0 \mathrm{~L} \cdot \mathrm{s}^{-1}\right)$ at the outlet of the Vollnkirchener Bach.

Figure 6. Hydrograph separation for stormflow event 26-27 May, 2013 with (A) hourly precipitation $\left(\mathrm{mm} \cdot \mathrm{h}^{-1}\right)$, discharge at upper RBC-flume (Figure 2, site 18) and calculated event water contribution at lower RBC-flume (site 13) $\left(\mathrm{L} \cdot \mathrm{s}^{-1}\right)$; (B) pre-event $\delta^{2} \mathrm{H}$ in groundwater in the meadow (piezometers $3,6,21), \delta^{2} \mathrm{H}$ in stream and bulk rainfall, and (C) groundwater levels below ground $(\mathrm{m})$ for selected piezometers in the meadow $(1-6,21)$ and in the upstream section $(31,32)$.

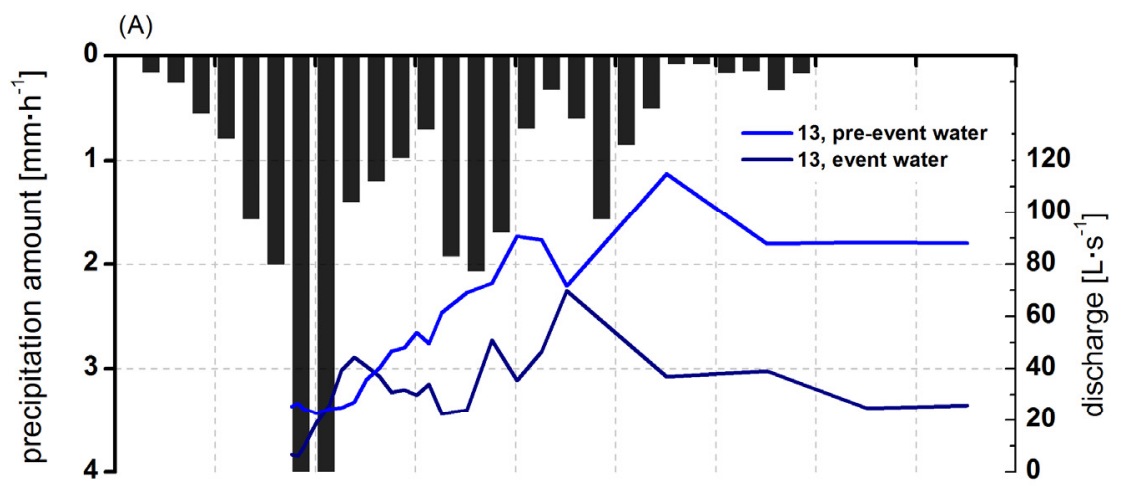

(B)

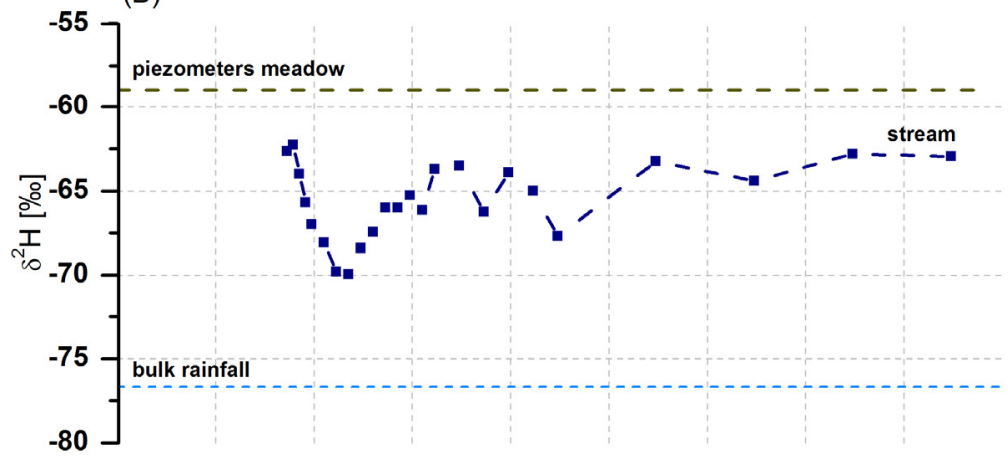

(C)

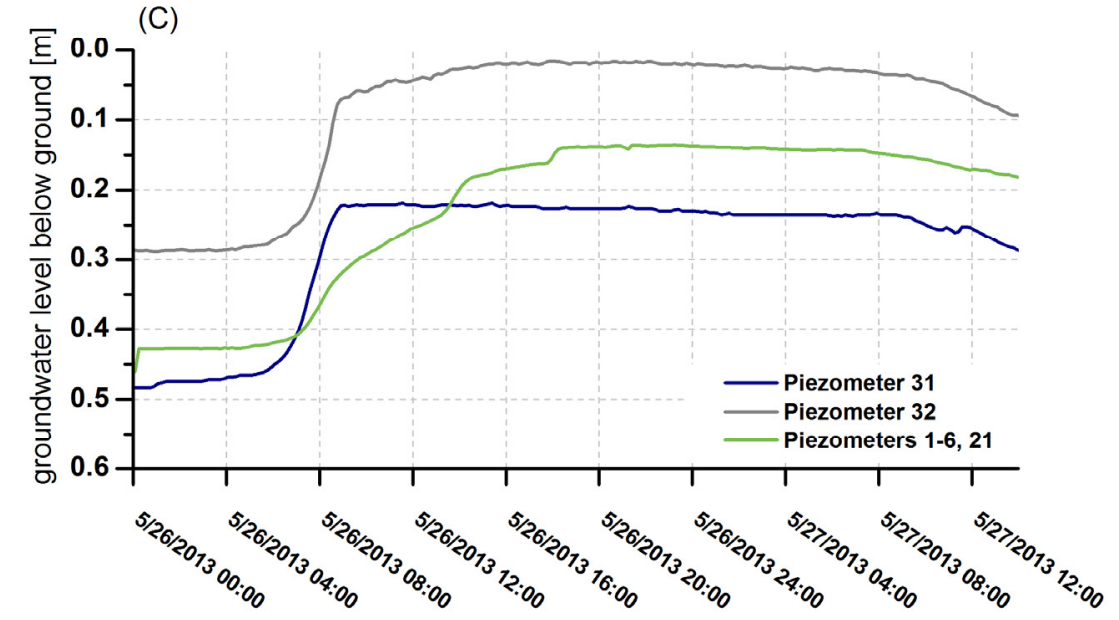


Figure 7. (A) Geological map including classification of the stream sections in gaining/losing reaches $\left(\mathrm{L} \cdot \mathrm{s}^{-1}\right)$; and $(\mathbf{B})$ relationship between stream length $(\mathrm{km})$, discharge $\mathrm{Q}\left(\mathrm{L} \cdot \mathrm{s}^{-1}\right) \pm 5 \%$ error, and subcatchment area $\left(\mathrm{km}^{2}\right)$. The stream length is depicted from the headwater to the outlet from left to right. Note that tributaries are not included in Figure 7B.

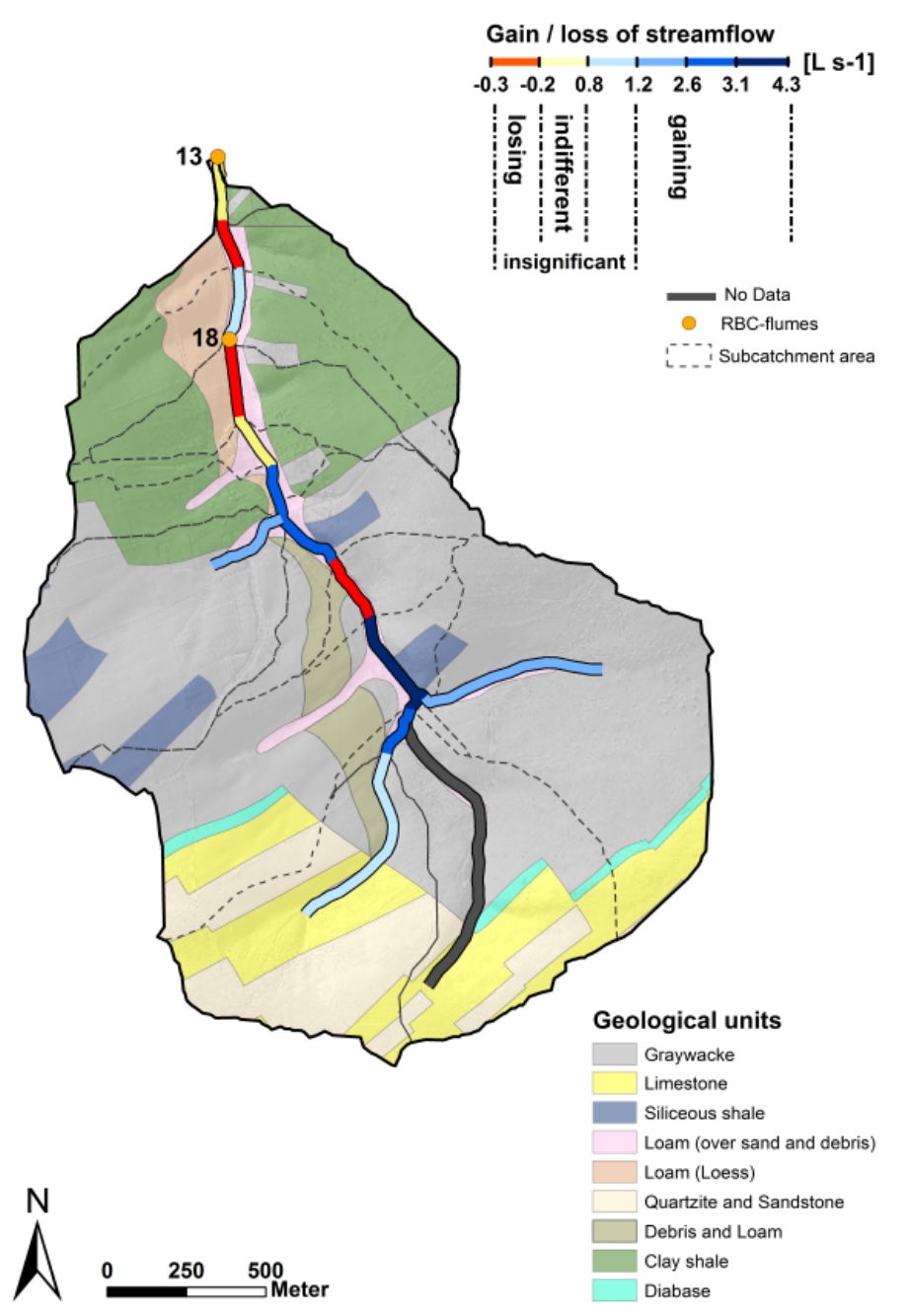

(A)

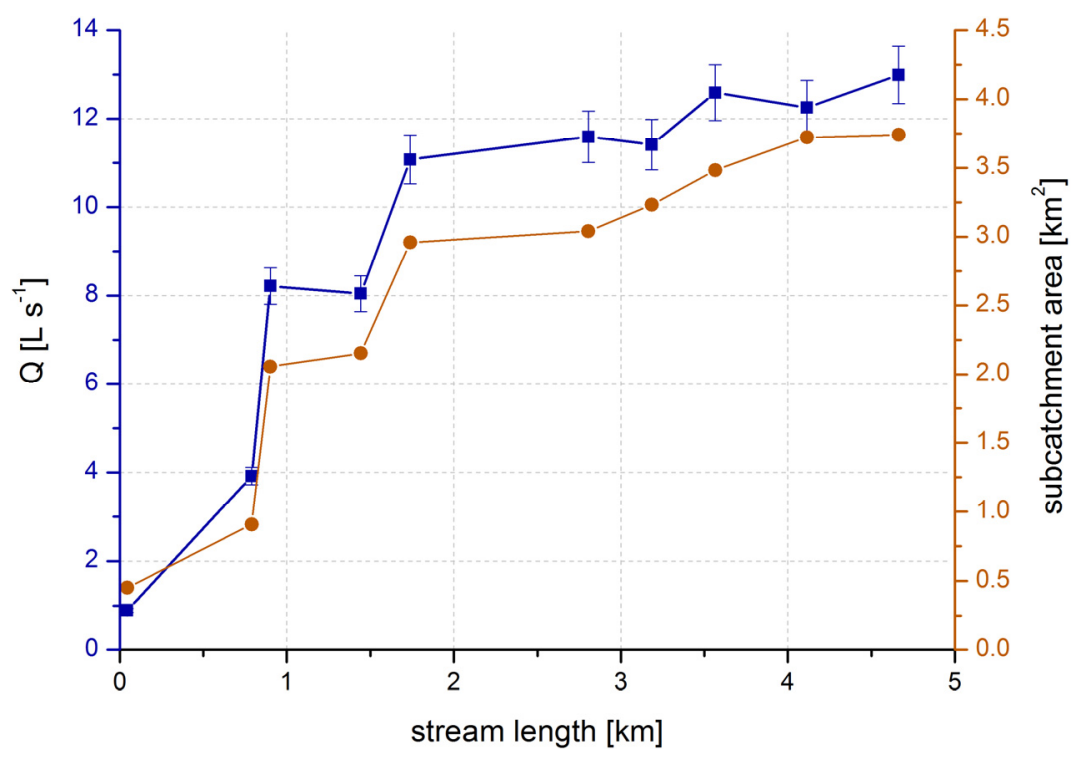

(B) 


\subsection{Groundwater Dynamics}

\subsubsection{Groundwater Flow Directions}

Generally, influent and effluent conditions were observed simultaneously at different stream sections of the Vollnkirchener Bach. During baseflow conditions as well as rainfall-runoff events the stream is constantly losing water to the groundwater (influent) west- and eastbound of the meadow at the catchment outlet (Figure 8A). Under arable land, groundwater flow directions of piezometers 25-29 followed topographic conditions and although showed no changes due to stream-stage fluctuations. In the upstream section effluent conditions were measured (piezometer 32-35). Due to topographic heights differences, groundwater head levels were higher (246 $\mathrm{m}$ a.s.1.) at the upper reach and lower levels were observed at the lower reach of the creek (234 $\mathrm{m}$ a.s.1.) (Figure 8). Since for piezometers 30 and 31 only manual measurements were available for a limited period, changes in groundwater flow directions could only exemplary be shown for a wetting up phase from 22 November 2011 to 25 January 2012. Figure 9 depicts the rainfall-runoff conditions as well as piezometric response - exemplary shown for piezometers 26-29- throughout that period.

Figure 8. Groundwater head elevations ( $m$ a.s.1.) and flow directions along the Vollnkirchener Bach during a wetting up phase (22 November 2011-25 January 2012). (A) shows the initial groundwater flow directions (22 November 2011) and (B) groundwater flow directions at the end of the wetting up period (25 January 2012).Red dots indicate piezometers, orange dots stream depth observation points, and the dashed line a street. Arrows and contour lines show groundwater flow directions along the creek.

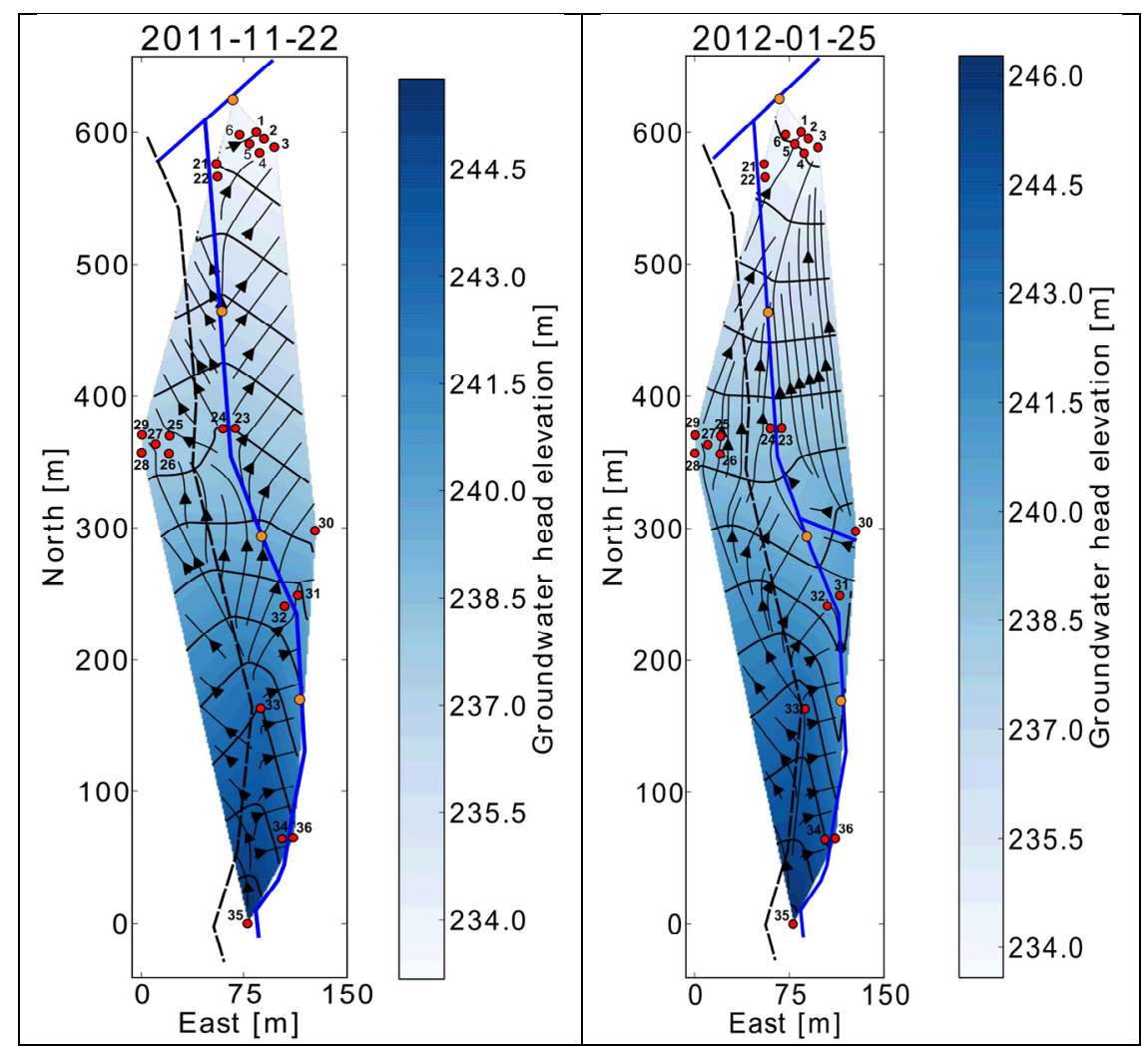

(A)

(B) 
Figure 9. (A) Hourly precipitation $\left(\mathrm{mm} \cdot \mathrm{h}^{-1}\right)$; (B) hourly discharge $\left(\mathrm{L} \cdot \mathrm{s}^{-1}\right)$ at the lower and upper RBC-flume (13, 18); and (C) 15 min mean groundwater head elevations (m a.s.1.) for piezometers $26-29( \pm$ SD, grey shaded) during the wetting up period (1 November 2011-1 February 2012). Note Mini-Divers ${ }^{\circledR}$ malfunctions: from 14 December 2011, at site 18, from 20 January 2012, at site 13.
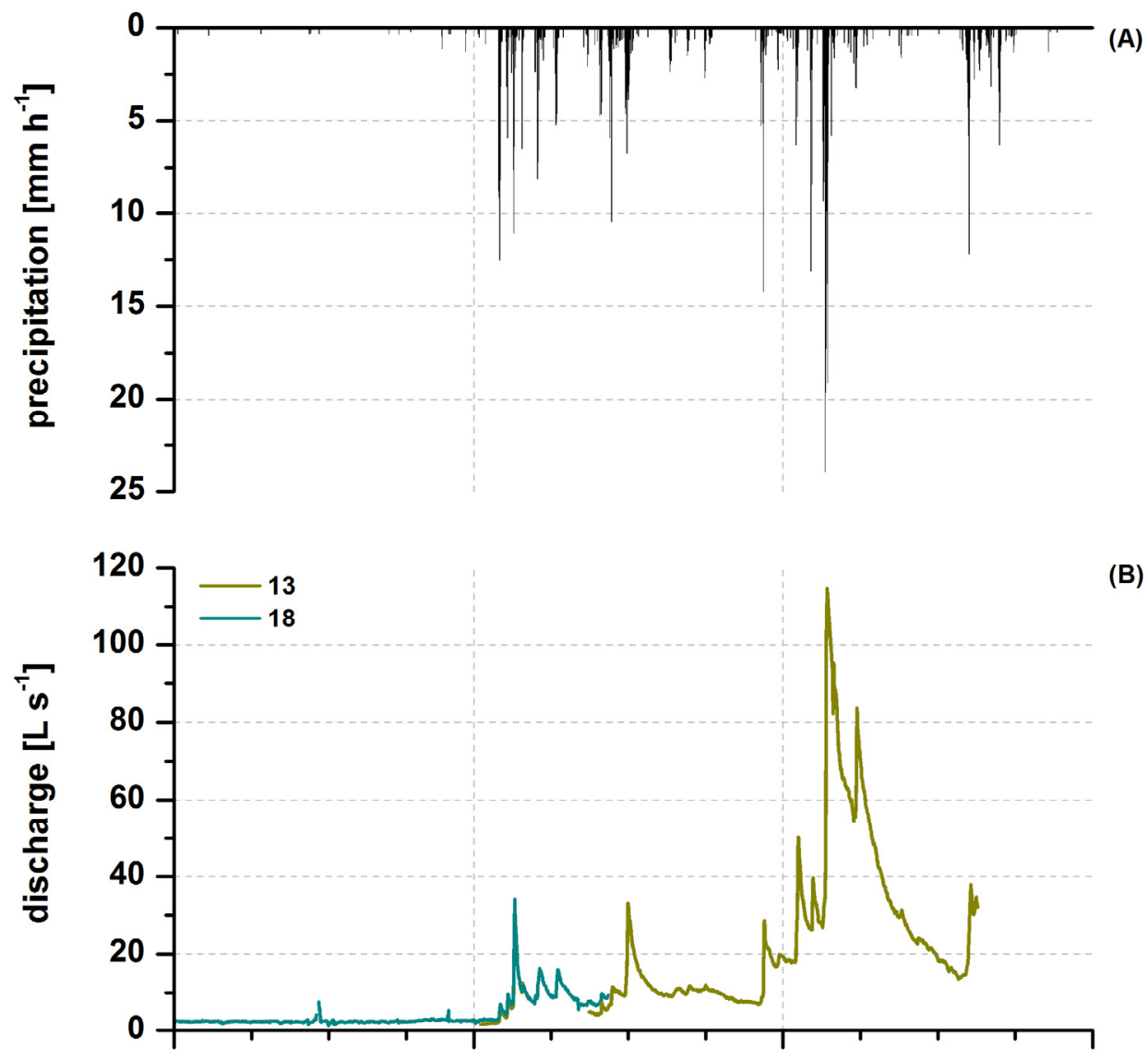

(B)

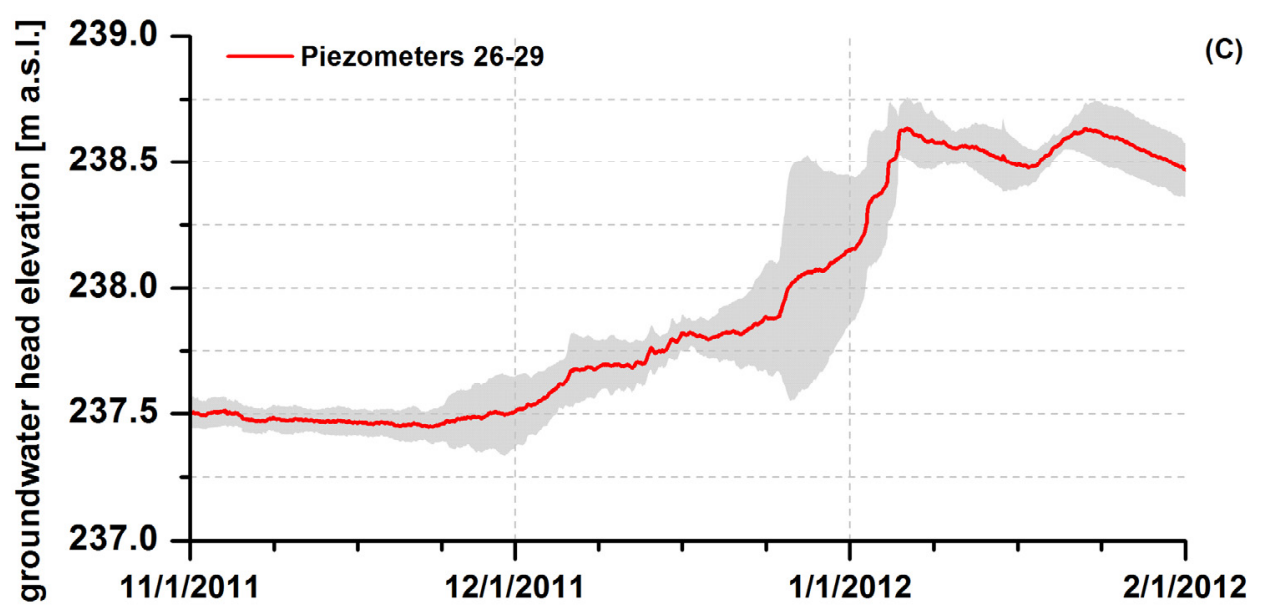

During November 2011 dry conditions were predominant with an antecedent wetness AP30d of $8.5 \mathrm{~mm}$ prior to the next rainfall event on 3 December, 2011. Streamflow measured at site 18 varied from 1.2 to $7.6 \mathrm{~L} \cdot \mathrm{s}^{-1}$ (Figure 9B). From that point on, moderate rainfall events resulted in only small rises of the hydrograph, nonetheless gradually filling up catchment's water storages associated with rising groundwater head elevations (Figure 9C) from $237.5 \pm 0.1 \mathrm{~m}$ to finally $238.6 \pm 0.1 \mathrm{~m}$ at the end 
of the wetting up phase. Precipitation events from 4 to 6 January 2012, with a huge rainfall sum of 166 mm subsequently caused a significant increase in discharge to $>114 \mathrm{~L} \cdot \mathrm{s}^{-1}$, which moreover caused a rise in groundwater head elevations $(+0.2 \mathrm{~m}$ ) (Figure 9). Finally, a fundamental groundwater flow reversal was observed on 10 January, 2012. From that point on, an ephemeral tributary rose in the clay shale-graywacke dominated forested site eastbound of the creek and drained into the Vollnkirchener Bach near to piezometer 30 (Figure 8B, Figure 10). This is indicated by arrows pointing to the creek (Figure 8B) and groundwater flow directions parallel to the stream following the topographic gradient in northbound direction.

Moreover, previously losing conditions were inversed in the western downstream section (from site 23 on). However, influent conditions eastbound of the meadow at the catchment outlet (piezometers $1-6,21,22$ ) were still apparent, but westbound this downstream reach groundwater inflow was observed (Figure 8B). Nevertheless, no changes in groundwater flow directions under arable land (piezometers 25-29) were detected. Gaining conditions measured in the upper stream reach (piezometer 32-35) even expanded during the wetting up phase. These diverse groundwater flow dynamics lasted until 25 January 2012 (Figure 8B).

Figure 10. Photos showing the ephemeral tributary (A) originating from the forest and (B) draining into the stream near to piezometer 30 .
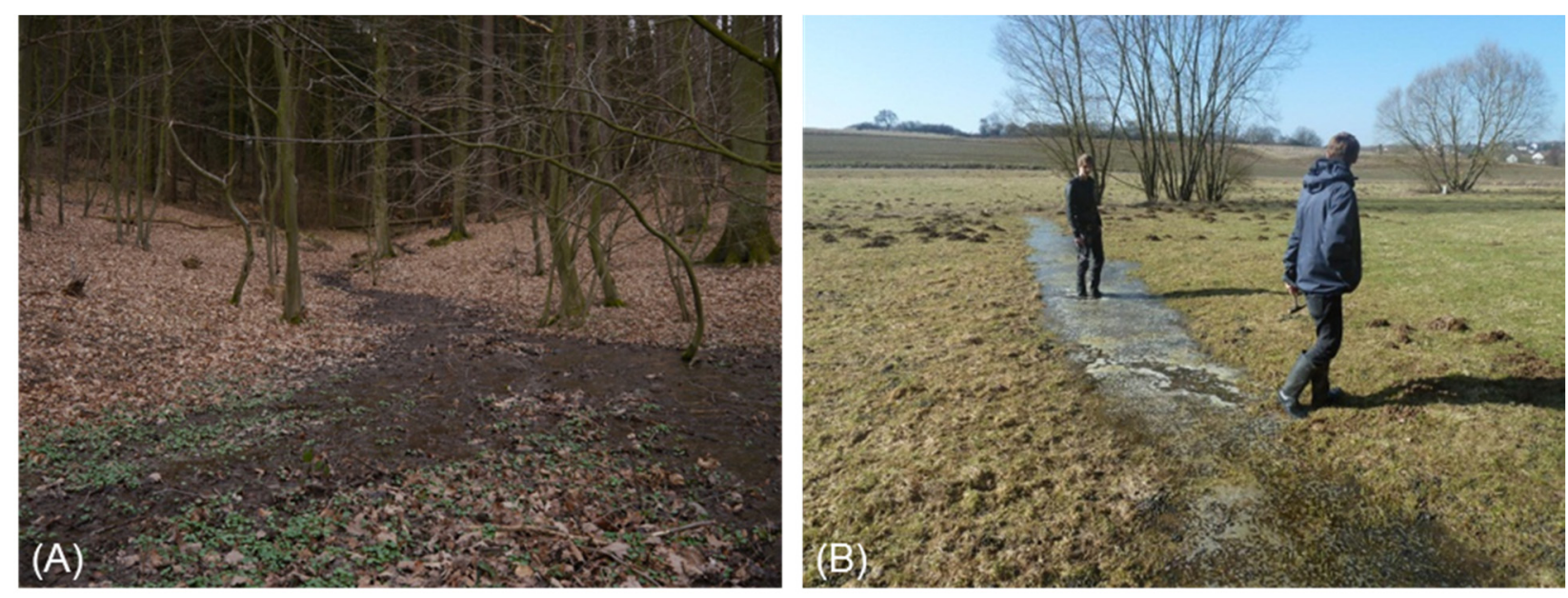

\subsubsection{Aquifer Hydraulic Conductivity}

Groundwater hydraulic conductivities measured via rising head slug tests along the Vollnkirchener

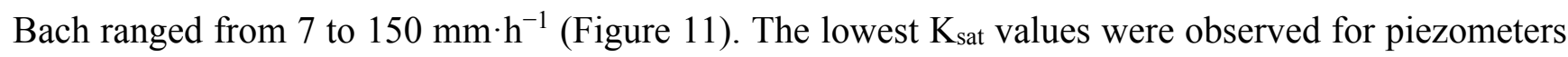
32 and $36\left(7-14 \mathrm{~mm} \cdot \mathrm{h}^{-1}\right)$, second smallest values for 32 and $34\left(14-20 \mathrm{~mm} \cdot \mathrm{h}^{-1}\right)$. Gradually increasing $\mathrm{K}_{\text {sat }}$ values were measured northbound (downstream). Near the conjunction of the Schwingbach with the Vollnkirchener Bach, the highest hydraulic conductivities were determined for piezometers $1\left(150 \mathrm{~mm} \cdot \mathrm{h}^{-1}\right)$ and $22\left(100 \mathrm{~mm} \cdot \mathrm{h}^{-1}\right)$ showing generally $8-21$ magnitudes higher conductivities in comparison to piezometers 31-36. Despite of highly variable values for piezometers at the catchment outlet $(1-6,21,22)$, marked spatial differences between the up- and downstream section were obvious. 
Figure 11. Land use map with measured (red dots) and interpolated (bluish areas) $\mathrm{K}_{\text {sat }}$ values $\left(\mathrm{mm} \cdot \mathrm{h}^{-1}\right)$ for piezometers along the downstream section of the Vollnkirchener Bach.

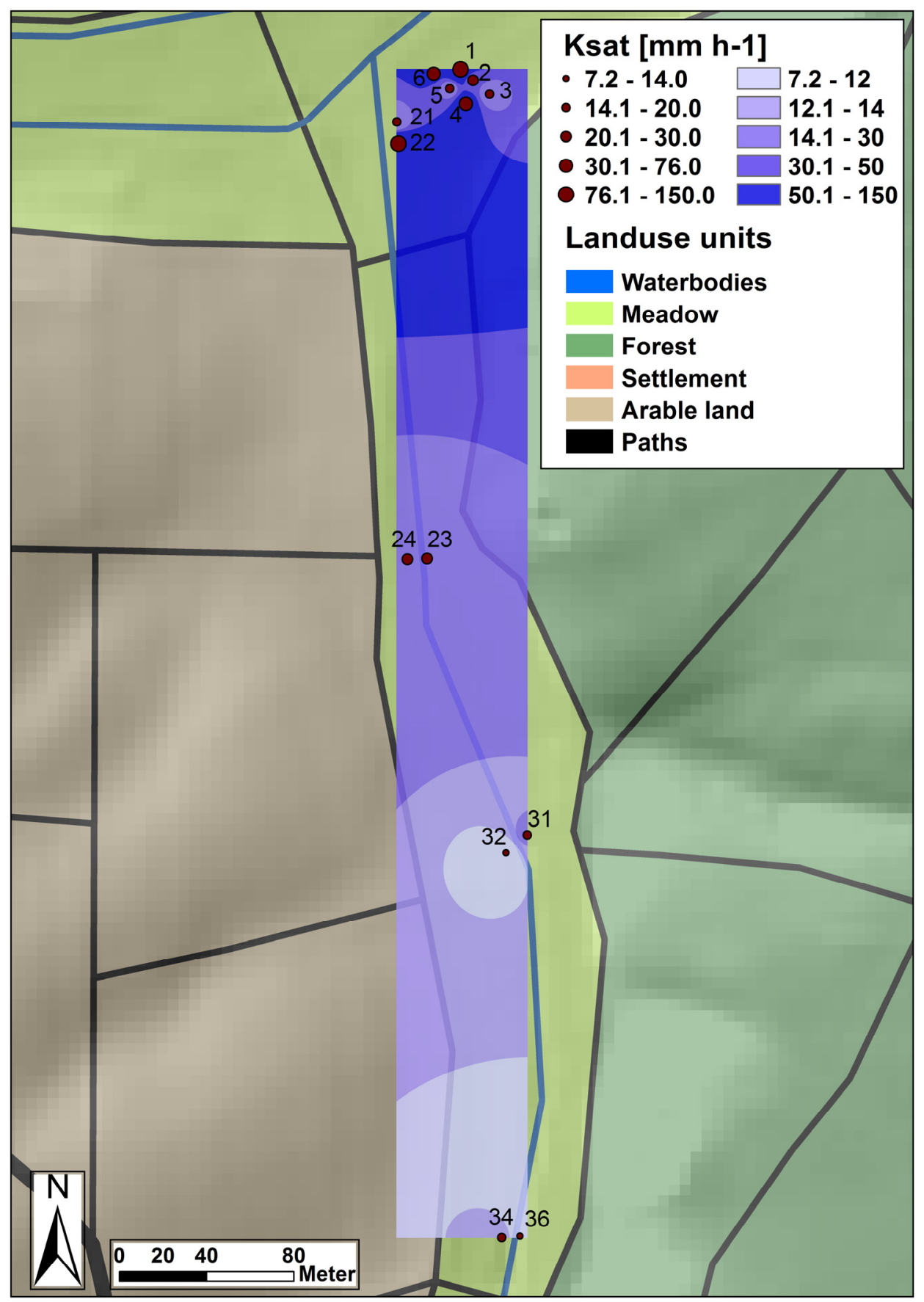

\subsubsection{Groundwater Head Level Correlations and Piezometric Stream Stage Response}

Correlation analyses were performed among the mean daily groundwater head elevations of automatically monitored piezometers, and furthermore, between the mean daily discharge and the groundwater table response (Table 4). High to medium groundwater head level correlations were determined within piezometers in the meadow near the conjunction of the streams $(1-6,21,22)$, as well as with piezometers 23 and 24, which are located $140 \mathrm{~m}$ upstream. Piezometers under arable land (25-29) were highly correlated among themselves $\left(\mathrm{R}^{2}=0.82-1.0\right)$. As a result of logger malfunctions, the shortest time series was recorded for piezometer 29, therefore, showing low to no correlations with 
groundwater head elevations of other piezometers. Groundwater table elevations recorded at sites 34 and 36 were well-correlating with piezometers $1-5$ and 22-24 exhibiting similar groundwater reactions. Due to the high correlation coefficient between the mean daily discharge at the lower and upper RBC-flume $\left(\mathrm{R}^{2}=0.96\right)$, correlations between discharge and groundwater head elevations were almost identical for both gauging stations. Good to medium correlations could be identified for mean daily discharge at both gauging stations with piezometers 1-24 at the lower stream reach, medium to low correlations for piezometers under the arable field (25-29), as well as for piezometer 31; whereas groundwater head elevations at sites 32-36 showed medium to high correlations with mean daily discharge.

This corresponded with the observation that groundwater head elevations closely followed stream runoff-dynamics and responded to stormflow events with rising head levels (Figure 12). Groundwater showed the highest head levels from the end of December to the mid of June (Figure 12), this was well-marked for piezometers located directly beside the stream $(23,24)$ as well as for piezometers under arable land (25-29). Due to higher standard deviations (SD) this is not immediately obvious for piezometers near the Vollnkirchener Bach outlet (1-6, 21, 22). Groundwater head elevations under arable land showed the smallest standard deviation (up to $\pm 0.1 \mathrm{~m}$ ), while groundwater head levels under meadow differed widely from the mean (up to $\pm 0.6 \mathrm{~m}$ ), although well-correlating among themselves. Generally, mean annual groundwater tables fluctuated within $\pm 1 \mathrm{~m}$ for all sites during the water year 2012-2013. Significant groundwater response could be observed for a snowmelt event during February 2013. Moreover, wet conditions during May 2013 were also apparent in the groundwater body. However, moderate rainfall events $\left(5-6 \mathrm{~mm} \cdot \mathrm{d}^{-1}\right)$ recorded at the end of July 2013 caused no rise in stream stage, but groundwater levels increased (meadow near the outlet: $+0.4 \mathrm{~m}$, piezometer $23-24:+0.8 \mathrm{~m}$, arable land: $+0.1 \mathrm{~m}$ ). The groundwater body under arable field with its piezometers 25-29 is most likely hydrologically disconnected to the stream due to a street blocking the bidirectional exchange of water. A continuous decline in the water table under arable land was observed from June-October 2013, representing a decrease in wetness. Due to a greater exchange of streamwater and meadows, this effect was not apparent in piezometers 1-6 and 21-24.

Because of smaller distances to the stream, water level loggers of piezometers in the meadow were exposed to floods and got frequently defective, leading to higher standard deviations. Unfortunately, logger breakdown due to piezometer overfill occurred in the meadow during the storm event starting on 28 January, 2013, which is therefore not clearly measured in the meadow. Piezometers under the hillslope arable site were never flooded because of a deep groundwater body (Table 1). 
Table 4. Results of correlation analyses $\left(\mathrm{R}^{2}\right)$ among mean daily groundwater head elevations ( $\mathrm{m}$ a.s.1.) of automatically monitored piezometers and mean daily discharge $\left(\mathrm{L} \cdot \mathrm{s}^{-1}\right)$. Correlations are classified into high $(0.80-1.0$, dark grey shaded), medium $(0.60-0.79$, lighter grey shaded), low correlations $(0.40-0.59$, light grey shaded), and no correlations $(<0.39$, no shading).

\begin{tabular}{|c|c|c|c|c|c|c|c|c|c|c|c|c|c|c|c|c|c|c|c|c|c|c|c|}
\hline Location & Site & 13 & 18 & 1 & 2 & 3 & 4 & 5 & 6 & 21 & 22 & 23 & 24 & 25 & 26 & 27 & 28 & 29 & 31 & 32 & 34 & 35 & 36 \\
\hline Lower RBC-flume & 13 & $\mathrm{x}$ & & & & & & & & & & & & & & & & & & & & & \\
\hline Upper RBC-flume & 18 & 0.96 & $\mathrm{x}$ & & & & & & & & & & & & & & & & & & & & \\
\hline \multirow{8}{*}{ Meadow (outlet) } & 1 & 0.79 & 0.75 & $\mathrm{x}$ & & & & & & & & & & & & & & & & & & & \\
\hline & 2 & 0.75 & 0.70 & 0.95 & $\mathrm{x}$ & & & & & & & & & & & & & & & & & & \\
\hline & 3 & 0.85 & 0.82 & 0.88 & 0.88 & $\mathrm{x}$ & & & & & & & & & & & & & & & & & \\
\hline & 4 & 0.83 & 0.78 & 0.78 & 0.80 & 0.89 & $\mathrm{x}$ & & & & & & & & & & & & & & & & \\
\hline & 5 & 0.89 & 0.85 & 0.94 & 0.92 & 0.93 & 0.89 & $\mathrm{x}$ & & & & & & & & & & & & & & & \\
\hline & 6 & 0.76 & 0.81 & 0.85 & 0.82 & 0.84 & 0.70 & 0.96 & $\mathrm{x}$ & & & & & & & & & & & & & & \\
\hline & 21 & 0.81 & 0.85 & 0.81 & 0.78 & 0.84 & 0.72 & 0.94 & 0.89 & $\mathrm{x}$ & & & & & & & & & & & & & \\
\hline & 22 & 0.73 & 0.68 & 0.89 & 0.89 & 0.87 & 0.49 & 0.90 & 0.94 & 0.90 & $\mathrm{x}$ & & & & & & & & & & & & \\
\hline Eastern stream-site & 23 & 0.90 & 0.88 & 0.85 & 0.82 & 0.86 & 0.87 & 0.92 & 0.77 & 0.80 & 0.80 & $\mathrm{x}$ & & & & & & & & & & & \\
\hline Western stream-site & 24 & 0.92 & 0.88 & 0.87 & 0.83 & 0.86 & 0.85 & 0.91 & 0.77 & 0.79 & 0.84 & 0.96 & $\mathrm{x}$ & & & & & & & & & & \\
\hline \multirow{5}{*}{$\begin{array}{l}\text { Arable land, } \\
\text { western stream-site }\end{array}$} & 25 & 0.51 & 0.46 & 0.43 & 0.43 & 0.54 & 0.81 & 0.54 & 0.36 & 0.25 & 0.01 & 0.52 & 0.57 & $\mathrm{x}$ & & & & & & & & & \\
\hline & 26 & 0.58 & 0.46 & 0.49 & 0.48 & 0.63 & 0.84 & 0.51 & 0.34 & 0.39 & 0.00 & 0.60 & 0.62 & 1.00 & $\mathrm{x}$ & & & & & & & & \\
\hline & 27 & 0.70 & 0.51 & 0.50 & 0.50 & 0.74 & 0.78 & 0.15 & 0.43 & 0.55 & 0.00 & 0.68 & 0.68 & 0.91 & 0.99 & $\mathrm{x}$ & & & & & & & \\
\hline & 28 & 0.59 & 0.48 & 0.51 & 0.50 & 0.64 & 0.85 & 0.52 & 0.36 & 0.39 & 0.00 & 0.61 & 0.63 & 1.00 & 1.00 & 1.00 & $\mathrm{x}$ & & & & & & \\
\hline & 29 & 0.29 & 0.50 & 0.20 & 0.44 & 0.32 & 0.60 & 0.00 & 0.04 & 0.40 & 0.10 & 0.52 & 0.61 & 0.82 & 0.98 & 0.86 & 0.98 & $\mathrm{x}$ & & & & & \\
\hline Eastern stream-site & 31 & 0.22 & 0.20 & 0.30 & 0.28 & 0.26 & 0.17 & 0.35 & 0.23 & 0.47 & 0.67 & 0.18 & 0.18 & 0.02 & 0.05 & 0.01 & 0.07 & 0.22 & $\mathrm{x}$ & & & & \\
\hline $\begin{array}{l}\text { Towards } 31 \text {, western } \\
\text { stream-site }\end{array}$ & 32 & 0.69 & 0.67 & 0.57 & 0.47 & 0.56 & 0.47 & 0.78 & 0.54 & 0.66 & 0.63 & 0.59 & 0.63 & 0.15 & 0.22 & 0.48 & 0.24 & 0.20 & 0.40 & $\mathrm{x}$ & & & \\
\hline Western stream-site & 34 & 0.92 & 0.87 & 0.88 & 0.82 & 0.85 & 0.90 & 0.94 & 0.74 & 0.78 & 0.81 & 0.93 & 0.95 & 0.61 & 0.59 & 0.58 & 0.61 & 0.35 & 0.20 & 0.67 & $\mathrm{x}$ & & \\
\hline $\begin{array}{l}\text { Beside } 18 \text {, western } \\
\text { stream-site }\end{array}$ & 35 & 0.66 & 0.51 & 0.69 & 0.69 & 0.68 & 0.93 & 0.87 & 0.55 & 0.64 & 0.33 & 0.61 & 0.67 & 0.94 & 0.81 & 0.82 & 0.80 & 0.00 & 0.97 & 0.60 & 0.66 & $\mathrm{x}$ & \\
\hline $\begin{array}{l}\text { Towards } 34 \text {, eastern } \\
\text { stream-site }\end{array}$ & 36 & 0.86 & 0.82 & 0.91 & 0.87 & 0.92 & 0.81 & 0.93 & 0.73 & 0.63 & 0.92 & 0.86 & 0.89 & 0.59 & 0.58 & 0.19 & 0.61 & 0.00 & 0.09 & 0.46 & 0.91 & 0.94 & $x$ \\
\hline
\end{tabular}


Figure 12. Time series of daily precipitation $\left(\mathrm{mm} \cdot \mathrm{d}^{-1}\right)$, discharge at the lower and upper RBC-flume $(13,18)\left(\mathrm{L} \cdot \mathrm{s}^{-1}\right)$, and 15 min-mean groundwater head elevations (m a.s.1.) $\pm \mathrm{SD}$ (grey shaded) for the water year 2012-2013 (if only data for one piezometer were available, no SD is depicted). Note the different scale of the uppermost groundwater graph.

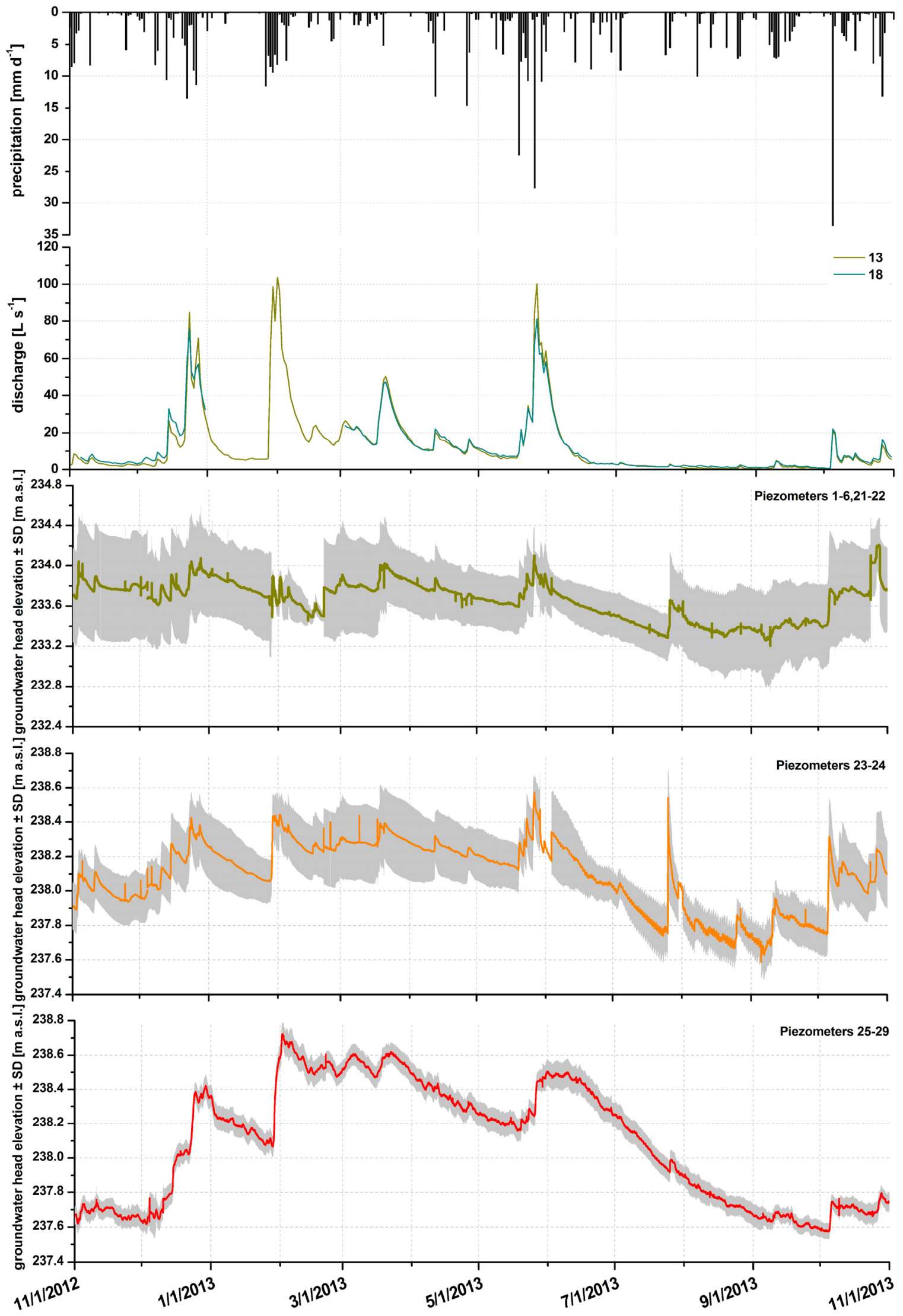




\section{Discussion}

The results of the flow duration curve analyses showed similar discharge occurrence frequencies for the up- and downstream gauging stations $(18,13)$. Condensing a wealth of hydrologic information into a single graph [52], an overview of the general flow characteristics of the Vollnkirchener Bach was gained. However, flow duration curve analyses could not cover the event-based differences in discharge between both gauging stations. Therefore, lag-to-peak time analyses were performed to further analyze streamflow responses to rainfall input (Figure 5, Table 3). Taking up the first objective, streamflow responded highly variable throughout the water year. Four different types of hydrograph reactions were identified showing diverse lag-times for both gauging stations (Figure 5). Generally, lag-times were slightly affected by rainfall amounts. This is in line with other studies that demonstrate the negligible effect of rainfall intensities on lag-times in vegetated catchments [15,53], or which observed no correlations between total runoff or runoff coefficients and maximum or average rainfall intensities [54]. Moreover, antecedent wetness conditions (AP values) showed no influence on the timing of the hydrologic responses but had a weak control on the initial discharge $\mathrm{Q}_{0}$. $\mathrm{Q}_{\max }$ was neither influenced by initial moisture conditions, nor by rainfall amounts. However, quick timing events mainly occurred in dryer periods $\left(\mathrm{Q}_{0}<5 \mathrm{~L} \cdot \mathrm{s}^{-1}\right)$, potentially related to soil hydrophobicity [55,56] and silting. The hydrophobic effect favors surface runoff over unsaturated near-stream zones by limiting infiltration [56] and subsequently causing quickflow.

An inter-seasonal trend affecting rainfall-runoff event types could be observed with combined sewer overflow-induced events occurring during dry periods and gaining conditions towards the lower RBC-flume during wet periods. Nevertheless, we were not able to generalize that specific conditions (rainfall amount, $\mathrm{Q}_{0}, \mathrm{AP}$ ) cause a specific runoff-event type with defined lag-times. Event-scale rainfall-runoff relationships and analyses of variables that potentially influence the observed lag-times provide a number of general findings concerning the hydrological response of the Vollnkirchener Bach catchment. Combining results of flow duration curve and lag-to-peak time analyses revealed that gaining conditions towards the downstream section mainly occurred on an event-basis and losing conditions during baseflow.

Using differences in isotopic ratios to establish the sources of water that generate streamflow revealed a high rainfall influence on runoff measured at the basin outlet for one specific storm event. With growing rainfall amount, increasing event water contributions were measured, which was in line with other studies measuring enhanced event water quantities with increasing intensity of the storms [6,57-59]. A direct correspondence of precipitation intensity and event water contribution suggests a direct and rapid water delivery mechanism. Groundwater levels reacted as quickly as stream water to precipitation input, indicating that the Vollnkirchener Bach is a highly responsive basin and moreover, implying that saturation-excess surface flow dominate this runoff response. This is underlined by the fact that the lower RBC-flume was overflowed during this storm event and AP5d was high. Short-term responses to rainfall-runoff events are evident in the groundwater table records of many shallow piezometers throughout the catchment not only for this specific storm event. A rise in the water table coincided with periods of precipitation but varied among piezometers in magnitude and duration. Comparable to reference [54], groundwater levels can be understood as a rough estimate for catchment's wetness conditions converting a large percentage of rainfall to runoff when the initial groundwater table 
is shallow. Nevertheless, to confirm if the flow mechanism and with that event water contribution differs throughout the year, a comparison with similar events is essential. Typically water stored within the catchment dominates the stream hydrograph, except during certain periods when large volumes of water are released and quickly reach the stream [60], which was observed for the examined event. Moreover, the assumptions implicit in the hydrograph separation technique are still problematic [61] and the method does not account for spatial variability, which however, becomes more significant in larger catchments [61]. Additionally, incremental rain gauging better captures event characteristics, since rainfall isotopic values are known to vary throughout a storm event [12,62,63]. Furthermore, references $[35,61]$ highlighted the danger of assuming that "old" or pre-event water is synonymous with groundwater, since vadose water — not accounted for in a two-component model—may be isotopically heavier than groundwater or baseflow as a result of summer/autumn precipitation input being enriched in $\delta^{2} \mathrm{H}$ or $\delta^{18} \mathrm{O}$ and also varying with depth. Accounting for a distinct soil or groundwater isotopic signature, a three-component mixing model is suggested to be applied in the future because groundwater seems to play a major role in the catchment.

Quantifying gaining and losing reaches along the Vollnkirchener Bach targeting objective 2, showed that both types of stream-groundwater interactions occurred in parallel during low flow. Gaining reaches dominated in the headwaters, located in limestone, sandstone, and quartzite regions, which are known to serve as aquifers with the capacity to store large volumes of water $[17,18]$. Near to the wetland in the upper stream reach the geological map depicts an area of loam over sand and debris (Figure 7A), which is typically found under the Vollnkirchener Bach streambed indicating that in former times there must have been a tributary to the creek as well. The same could be true for the loamy deposits over sand and debris located upstream of the channeled tributary in the middle stream reach, also identified as gaining stream section (Figure 1D and 7A). At the lower stream stretch insignificantly gaining, losing or indifferent reaches occurred due to small differences in measured streamflow (Figure 7B). This could be likewise a result from measuring inaccuracies ( $\pm 5 \%$ error of the salt dilution method). Nevertheless, a change in geology (i.e., clay shale dominated sites in the north of the Vollnkirchener Bach catchment serve as aquicludes [18]) leads to a change in flow paths (Figure 7A). This was in accordance with other studies $[64,65]$ highlighting the geological impact on groundwater-surface water interactions.

Results of the incremental flow gauging underlined somewhat results of the discharge differences measured between the upper and lower RBC-flume (Figure 3, small inset). Whereby, automatically recorded values via Mini-Diver ${ }^{\circledR}$ are known to be more precise $( \pm 5 \mathrm{~mm})$ than salt dilution gauging, showing a loss of water between the up- and downstream section (catchment outlet) during baseflow. Furthermore, hydraulic conductivities $\left(K_{\text {sat }}\right)$ measured for piezometers located between the discharge gauging stations showed highest values for piezometers under the meadow at the catchment outlet, indicating the capability of stream losing large volumes of water to the groundwater. Vice versa, lowest

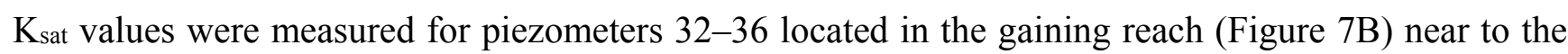
upper flume. Although $\mathrm{K}_{\text {sat }}$ values showed high spatial variability, zones of altered hydraulic conductivity surrounding the wellbore caused by drilling disturbance and smearing with clayey or silty sediments leading to the so-called skin effect [66-68] were not existing. Piezometers in this study have been installed and monitored since 2009, so that the skin effect decreasing over time might have less influence on the measured hydraulic conductivities. Nevertheless, reference [69] found that the spatial variability of hydraulic conductivity was greater than the variability of hydraulic conductivity between 
different measuring methods and reference [70] measured $\mathrm{K}_{\text {sat }}$ values that also varied by more than five orders of magnitude. Generally, measurements of hydraulic conductivity can be characterized by high uncertainties [11], and are being influenced by multiple factors [66,68,71].

Nevertheless, following the line of arguments, groundwater flow directions pointed out the same as $\mathrm{K}_{\text {sat }}$ values and the results of the incremental stream gauging already showed: effluent conditions in the stream section between piezometers 32-35 and influent conditions at the catchment's outlet (piezometers 1-6, 21-22). The simultaneous occurrence of influent and effluent conditions in different sections of the Vollnkirchener Bach combined with high spatial variability was in line with references $[4,72]$ who likewise observed temporal and spatial variability in the groundwater-surface water exchange fluxes.

A significant change in groundwater flow directions was attributed to an ephemeral tributary (Figures 9 and 10) originating from the eastbound forest site and draining into the stream during a wetting up phase. Due to a limitation in data for site 30, this phenomenon could only be depicted once. However, it is most likely to occur frequently during wet periods if catchment's saturation conditions are high. It could also be attributed to filling and spilling of depressions at the soil-bedrock interface [73,74] since wet conditions predominate. If groundwater tables reached a certain threshold after a long wet period, filling up catchment storages, spilling lead to the rise of the ephemeral tributary from the eastern forest site.

Analyzing groundwater head level reactions identified groups of similar hydrological response: Piezometers located under the meadow at the catchment outlet correlated well with piezometers midstream and piezometers under the arable field showed same head level variations among themselves. Linking groundwater dynamics to rainfall-runoff events showed that riparian groundwater head levels closely and rapidly followed stream-stage fluctuations showing medium to high correlation coefficients to catchment discharge (Figure 12, Table 4). This underlines the fact that the Vollnkirchener Bach is a highly responsive catchment with an intense interaction between the shallow groundwater and the creek. Comparable groundwater responses for an even smaller catchment $\left(0.04 \mathrm{~km}^{2}\right)$ were described in reference [75] stating that the shallow depth to the water table may allow the storm signal to move rapidly through the bedrock. However, groundwater tables under arable field were neither influenced by bidirectional water exchange with the stream (distances to stream of 44-66 m) nor by water quickly infiltrating into the soil subsequently causing a rapid rise in the shallow groundwater table as it could have been the case for piezometers with a minor depth below ground. Therefore, these piezometers can be understood as overall estimate for catchment's saturation status. In general, the connectivity of the stream with the groundwater system is highly temporal and spatial variable [15,72] and mainly influenced by the permeability of the stream bed and the aquifer, by the channel position in regard to the groundwater as well as by the geometry and size of the contact area $[41,72,76,77]$.

\section{Conclusions: Conceptualizing Groundwater-Surface Water Interactions from the Reach-Scale to the Catchment-Scale}

Based on the individual results of this research a conceptual model was developed proposing the principal flow system and interaction of surface water and groundwater along the Vollnkirchener Bach reach orientated south to north (Figure 13). Main water reservoirs are located upstream (artifical and fishponds, and a wetland), which generate the highest contribution to streamflow in the headwater area 
with effluent conditions. Before the Vollnkirchener Bach enters the village of Vollnkirchen, influent flow occurs. A channeled tributary joins the main water course causing net water gains in the village. Downstream Vollnkirchen diverse flow pathways are observed. However, the contribution of point sources such as an artificial drainage system and a wetland are negligible during baseflow (losing reach). During highflow, the combined sewer overflow becomes active and produces a pre-peak-discharge. Subsequently, the discharge at the lower RBC-flume exceeds the discharge at the upper flume. Moreover, during saturated conditions, mainly at winter times, the soil-bedrock system fills and finally forces water out of the ground to the surface, which subsequently drains into the creek as an ephemeral tributary. At the catchment outlet permanent influent conditions at baseflow are observed, leading to water losses to the groundwater causing an indifferent stream reach.

In general, the results of our multi-method approach helped to unravel flow pathways in the Vollnkirchener Bach catchment in a short research time. We showed that small catchment behavior in an anthropogenic influenced landscape is especially diverse underlining the fact that detailed distributed information is extremely essential for understanding catchment functioning. This knowledge can now be utilized to develop catchment specific process-based hydrological models.

Figure 13. Schematic of flow pathways along the Vollnkirchener creek based on hydrodynamic results. Groundwater flow directions are symbolized by arrows.

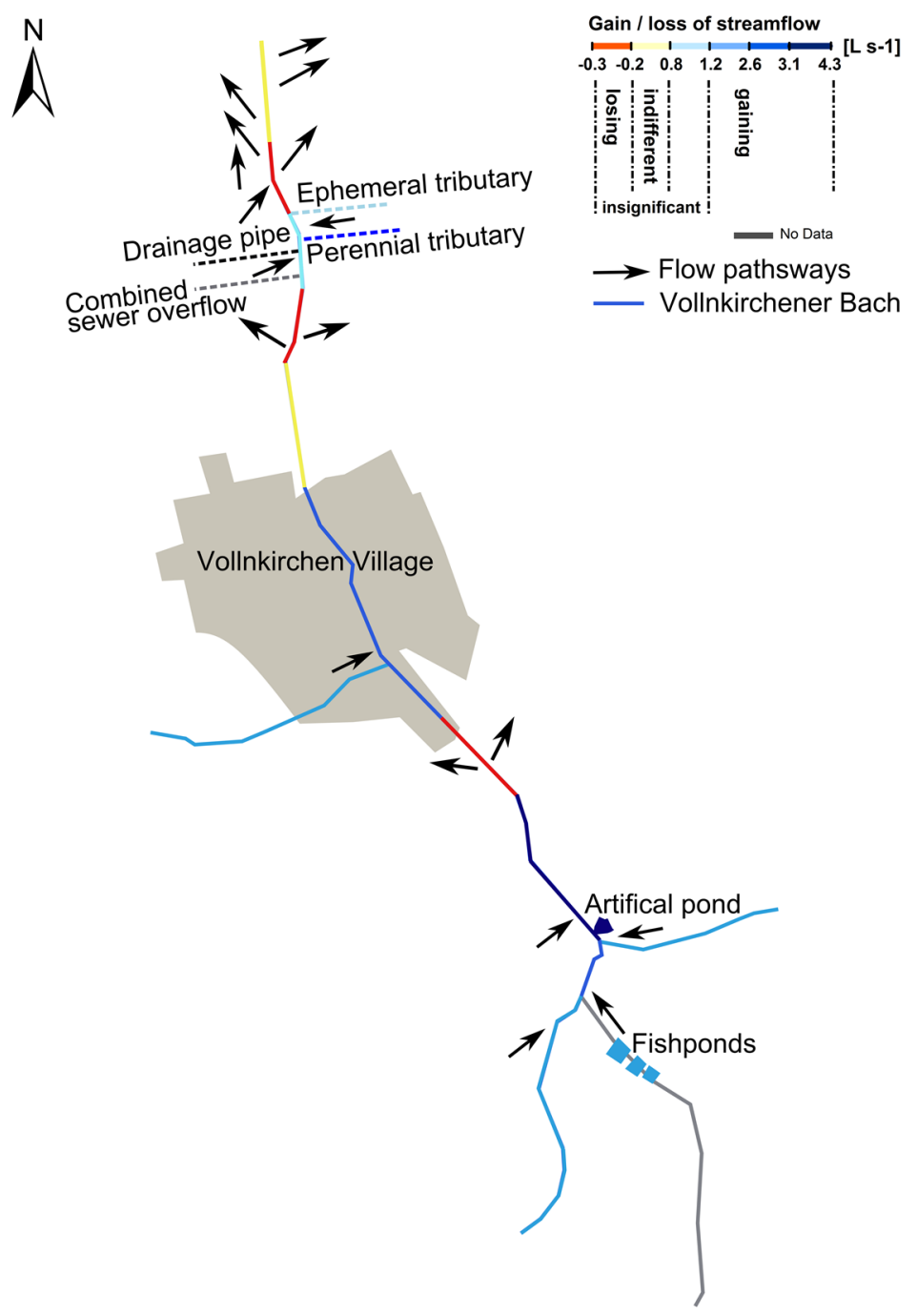




\section{Acknowledgments}

This study was conducted within the "Study landscape Schwingbachtal" [16]. Natalie Orlowski acknowledges finical support by the Friedrich-Ebert-Stiftung (Bonn, Germany). We further like to thank the Deutsche Forschungsgemeinschaft for generously funding grant BR2238/10-1 and the Justus Liebig University for grants provided to establish the Studienlandschaft Schwingbachtal. Special thanks go to Ruth Magh and Lisa Vogel, two of many students who conducted their BSc or MSc theses in the catchment and with that contributed to catchment process understanding. Thanks also to the colleagues of the Institute for Landscape Ecology and Resources Management for their valuable comments on the manuscript. Further, the support of the community Hüttenberg is greatly acknowledged.

\section{Author Contributions}

The manuscript was written by Natalie Orlowski, Philipp Kraft, and Lutz Breuer but all authors contributed to its preparation and review. The concept of the manuscript was mainly developed by Lutz Breuer, Philipp Kraft, and Hans-Georg Frede. Data collection and analyses was conducted by Natalie Orlowski and Florian Lauer.

\section{Conflicts of Interest}

The authors declare no conflict of interest.

\section{References}

1. Klapper, H. Historical Change of Large Alluvial Rivers: Western Europe; Petts, G.E., Möller, H., Roux, A.L., Eds.; John Wiley and Sons Ltd.: Chichester, UK, 1990; Volume 75, p. 355.

2. Allan, J.D. Landscapes and riverscapes: The influence of land use on stream ecosystems. Annu. Rev. Ecol. Evol. Syst. 2004, 35, 257-284.

3. Cox, M.H.; Su, G.W.; Constantz, J. Heat, chloride, and specific conductance as ground water tracers near streams. Ground Water 2007, 45, 187-195.

4. Unland, N.P.; Cartwright, I.; Andersen, M.S.; Rau, G.C.; Reed, J.; Gilfedder, B.S.; Atkinson, A.P.; Hofmann, H. Investigating the spatio-temporal variability in groundwater and surface water interactions: A multi-technique approach. Hydrol. Earth Syst. Sci. 2013, 17, 3437-3453.

5. Baxter, C.; Hauer, F.R.; Woessner, W.W. Measuring groundwater-stream water exchange: New techniques for installing minipiezometers and estimating hydraulic conductivity. Trans. Am. Fish. Soc. 2003, 132, 493-502.

6. Brown, V.A.; McDonnell, J.J.; Burns, D.A.; Kendall, C. The role of event water, a rapid shallow flow component, and catchment size in summer stormflow. J. Hydrol. 1999, 217, 171-190.

7. Crespo, P.; Buecker, A.; Feyen, J.; Vache, K.B.; Frede, H.-G.; Breuer, L. Preliminary evaluation of the runoff processes in a remote montane cloud forest basin using Mixing Model Analysis and Mean Transit Time. Hydrol. Process. 2012, 26, 3896-3910.

8. Didszun, J.; Uhlenbrook, S. Scaling of dominant runoff generation processes: Nested catchments approach using multiple tracers. Water Resour. Res. 2008, 44, doi:10.1029/2006WR005242. 
9. Munyaneza, O.; Wenninger, J.; Uhlenbrook, S. Identification of runoff generation processes using hydrometric and tracer methods in a meso-scale catchment in Rwanda. Hydrol. Earth Syst. Sci. 2012, 16, 1991-2004.

10. Hrachowitz, M.; Bohte, R.; Mul, M.L.; Bogaard, T.A.; Savenije, H.H.G.; Uhlenbrook, S. On the value of combined event runoff and tracer analysis to improve understanding of catchment functioning in a data-scarce semi-arid area. Hydrol. Earth Syst. Sci. 2011, 15, 2007-2024.

11. Kalbus, E.; Reinstorf, F.; Schirmer, M. Measuring methods for groundwater-Surface water interactions: a review. Hydrol. Earth Syst. Sci. 2006, 10, 873-887.

12. Kendall, C.; McDonnell, J.J. Isotope Tracers in Catchment Hydrology, 1st ed.; Elsevier: Amsterdam, The Netherlands, 1998.

13. Wels, C.; Cornett, R.J.; Lazerte, B.D. Hydrograph separation: A comparison of geochemical and isotopic tracers. J. Hydrol. 1991, 122, 253-274.

14. Wenninger, J.; Uhlenbrook, S.; Lorentz, S.; Leibundgut, C. Identification of runoff generation processes using combined hydrometric, tracer and geophysical methods in a headwater catchment in South Africa. Hydrol. Sci. J. 2008, 53, 65-80.

15. Lana-Renault, N.; Latron, J.; Regüés, D. Streamflow response and water-table dynamics in a sub-Mediterranean research catchment (Central Pyrenees). J. Hydrol. 2007, 347, 497-507.

16. Studienlandschaft Schwingbachtal. Available online: http://www.uni-giessen.de/cms/fbz/fb09/ institute/ilr/studienlandschaft/startseite (accessed on 17 February 2014).

17. Engineering Geology and the Environment; Marinos, P.G., Koukis, G.C., Tsiambaos, G.C., Stournaras, G.C., Eds.; CRC Press: Boca Raton, FL, USA, 1997.

18. Mazor, E. Chemical and Isotopic Groundwater Hydrology, 3rd ed.; CRC Press: Boca Raton, FL, USA, 2003.

19. Lauer, F.; Frede, H.-G.; Breuer, L. Uncertainty assessment of quantifying spatially concentrated groundwater discharge to small streams by distributed temperature sensing. Water Resour. Res. 2013, 49, 400-407.

20. DWD Deutscher Wetterdienst-Wetter und Klima, Bundesministerium für Verkehr und digitale Infrastruktur. Available online: http://dwd.de (accessed on 17 February 2014).

21. Fankhauser, R. Measurement properties of tipping bucket rain gauges and their influence on brain runoff simulation. Water Sci. Technol. 1997, 36, 7-12.

22. Maksimović, Č.; Bužek, L.; Petrović, J. Corrections of rainfall data obtained by tipping bucket rain gauge. Atmos. Res. 1991, 27, 45-53.

23. Xia, Y. Optimization and uncertainty estimates of WMO regression models for the systematic bias adjustment of NLDAS precipitation in the United States. J. Geophys. Res. Atmos. 2006, 111, doi:10.1029/2005JD006188.

24. HLUG Hessisches Landesamt für Umwelt und Geologie. Available online: http://www.hlug.de (accessed on 16 January 2014).

25. HVBG Hessische Verwaltung für Bodenmanagement und Geoinformation. Available online: http://www.hvbg.hessen.de (accessed on 16 January 2014).

26. Food and Agriculture Organization of the United Nations. World Reference Base for Soil Resources 2006: A Framework for International Classification, Correlation and Communication; World Soil Resources Reports 103; Food and Agriculture Organization: Rome, Italy, 2006. 
27. Eijkelkamp RBC flumes. Available online: http://en.eijkelkamp.com/products/water/hydrologicalresearch/water-discharge-measurements/rbc-flumes.htm (accessed on 13 January 2014).

28. Ali, H. Fundamentals of Irrigation and On-farm Water Management; Springer: New York, NY, USA, 2010; Volume 1.

29. Database-Studienlandschaft Schwingbachtal. Available online: http://fb09-pasig.umwelt.unigiessen.de:8081/ (accessed on 17 February 2014).

30. Davie, T. Fundamentals of Hydrology; Taylor \& Francis: Oxford, UK, 2008.

31. Dingman, S.L. Physical Hydrology, 2nd ed.; Waveland Press Inc.: Long Grove, IL, USA, 2002.

32. Rusjan, S.; Mikoš, M. Assessment of hydrological and seasonal controls over the nitrate flushing from a forested watershed using a data mining technique. Hydrol. Earth Syst. Sci. 2008, 12, 645-656.

33. Cook, P.G.; Herczeg, A.L. Environmental Tracers in Subsurface Hydrology; Springer: New York, NY, USA, 2000.

34. Bohté, R.; Mul, M.L.; Bogaard, T.A.; Savenije, H.H.G.; Uhlenbrook, S.; Kessler, T.C. Hydrograph separation and scale dependency of natural tracers in a semi-arid catchment. Hydrol. Earth Syst. Sci. Discuss. 2010, 7, 1343-1372.

35. Buttle, J.M. Isotope hydrograph separations and rapid delivery of pre-event water from drainage basins. Prog. Phys. Geogr. 1994, 18, 16-41.

36. Newman, B.; Tanweer, A.; Kurttas, T. IAEA Standard Operating Procedure for the Liquid-Water Stable Isotope Analyser 2009. Available online: http:/www-naweb.iaea.org/napc/ih/documents/ other/laser_procedure_rev12 (accessed on 5 February 2013).

37. Craig, H. Standard for reporting concentrations of deuterium and oxygen-18 in natural waters. Science 1961, 133, 1833-1834.

38. LGR Los Gatos Research. Greenhouse Gas, isotope and trace gas analyzers. Available online: http://www.lgrinc.com/ (accessed on 5 February 2013).

39. Cey, E.E.; Rudolph, D.L.; Parkin, G.W.; Aravena, R. Quantifying groundwater discharge to a small perennial stream in southern Ontario, Canada. J. Hydrol. 1998, 210, 21-37.

40. Harte, P.T.; Kiah, R.G. Measured river leakages using conventional streamflow techniques: the case of Souhegan River, New Hampshire, USA. Hydrogeol. J. 2009, 17, 409-424.

41. Winter, T.C.; Harvey, J.W.; Franke, O.L.; Alley, W.M. Ground Water and Surface Water: A Single Resource; U.S. Geological Survey Circular 1139; DIANE Publishing: Collingdale, PA, USA, 1999.

42. Day, T.J. On the precision of salt dilution gauging. J. Hydrol. 1976, 31, 293-306.

43. Moore, R.D. Introduction to Salt Dilution Gauging for Streamflow Measurement. Available online: http://www.docstoc.com/docs/74117190/Introduction-to-Salt-Dilution-Gaugingfor-Streamflow-Measurement (accessed on 13 September 2013).

44. Hongve, D. A revised procedure for discharge measurement by means of the salt dilution method. Hydrol. Process. 1987, 1, 267-270.

45. Kilpatrick, F.A.; Cobb, E.D. Measurements of discharge using tracers. In Techniques of Water-Resources Investigations, Book 3; U.S. Geological Survey: Reston, VA, USA, 1985; p. 52.

46. Boissonnat, J.-D.; Cazals, F. Smooth surface reconstruction via natural neighbour interpolation of distance functions. Comput. Geom. 2002, 22, 185-203. 
47. Zemansky, G.M.; McElwee, C.D. High-resolution slug testing. Ground Water 2005, 43, 222-230.

48. Butler, J.J., Jr. The Design, Performance, and Analysis of Slug Tests; CRC Press LLC: Boca Raton, FL, USA, 1997.

49. Singhal, B.B.S.; Gupta, R.P. Applied Hydrogeology of Fractured Rocks, 2nd ed.; Springer: New York, NY, USA, 2010.

50. Hvorslev, M.J. Time lag and soil permeability in ground-water observations. Bulletin 1951, 36, p. 50.

51. Anderson, A.E.; Weiler, M.; Alila, Y.; Hudson, R.O. Piezometric response in zones of a watershed with lateral preferential flow as a first-order control on subsurface flow. Hydrol. Process. 2010, 24, 2237-2247.

52. Vogel, R.M.; Fennessey, N.M. Flow duration curves ii: A review of applications in water resources planning. J. Am. Water Resour. Assoc. 1995, 31, 1029-1039.

53. Hewlett, J.D.; Fortson, J.C.; Cunningham, G.B. The effect of rainfall intensity on storm flow and peak discharge from forest land. Water Resour. Res. 1977, 13, 259-266.

54. Han, S.; Xu, D.; Wang, S. Runoff formation from plot, field, to small catchment with shallow groundwater table and dense drainage system in agricultural North Huaihe River Plain, China. Hydrol. Earth Syst. Sci. Discuss. 2012, 9, 4235-4262.

55. Biron, P.M.; Roy, A.G.; Courschesne, F.; Hendershot, W.H.; Côté, B.; Fyles, J. The effects of antecedent moisture conditions on the relationship of hydrology to hydrochemistry in a small forested watershed. Hydrol. Process. 1999, 13, 1541-1555.

56. Ali, G.A.; Roy, A.G.; Turmel, M.-C.; Courchesne, F. Multivariate analysis as a tool to infer hydrologic response types and controlling variables in a humid temperate catchment. Hydrol. Process. 2010, 24, 2912-2923.

57. Hooper, R.P.; Shoemaker, C.A. A Comparison of chemical and isotopic hydrograph separation. Water Resour. Res. 1986, 22, 1444-1454.

58. Caissie, D.; Pollock, T.L.; Cunjak, R.A. Variation in stream water chemistry and hydrograph separation in a small drainage basin. J. Hydrol. 1996, 178, 137-157.

59. Mul, M.L.; Savenije, H.H.G.; Uhlenbrook, S. Spatial rainfall variability and runoff response during an extreme event in a semi-arid catchment in the South Pare Mountains, Tanzania. Hydrol. Earth Syst. Sci. 2009, 13, 1659-1670.

60. Carey, S.K.; Quinton, W.L. Evaluating runoff generation during summer using hydrometric, stable isotope and hydrochemical methods in a discontinuous permafrost alpine catchment. Hydrol. Process. 2005, 19, 95-114.

61. Klaus, J.; McDonnell, J.J. Hydrograph separation using stable isotopes: Review and evaluation. J. Hydrol. 2013, 505, 47-64.

62. McDonnell, J.J.; Bonell, M.; Stewart, M.K.; Pearce, A.J. Deuterium variations in storm rainfall: Implications for stream hydrograph separation. Water Resour. Res. 1990, 26, 455-458.

63. Pionke, H.B.; Gburek, W.J.; Folmar, G.J. Quantifying stormflow components in a Pennsylvania watershed when ${ }^{18} \mathrm{O}$ input and storm conditions vary. J. Hydrol. 1993, 148, 169-187.

64. Banks, E.W.; Simmons, C.T.; Love, A.J.; Cranswick, R.; Werner, A.D.; Bestland, E.A.; Wood, M.; Wilson, T. Fractured bedrock and saprolite hydrogeologic controls on groundwater/surface-water interaction: A conceptual model (Australia). Hydrogeol. J. 2009, 17, 1969-1989. 
65. Banks, E. Groundwater-Surface Water Interactions in the Cox, Lenswood and Kersbrook Creek Catchments, Western Mount Lofty Ranges, South Australia; Science, Monitoring and Information Division, Department for Water, Government of Australia: Adeleide, Australia, 2010.

66. Mastrocicco, M.; Vignoli, G.; Colombani, N.; Zeid, N.A. Surface electrical resistivity tomography and hydrogeological characterization to constrain groundwater flow modeling in an agricultural field site near Ferrara (Italy). Environ. Earth Sci. 2010, 61, 311-322.

67. Yang, Y.J.; Gates, T.M. Wellbore skin effect in slug-test data analysis for low-permeability geologic materials. Ground Water 1997, 35, 931-937.

68. Rovey II, C.W.; Niemann, W. L. Wellskins and slug tests: where's the bias? J. Hydrol. 2001, 243, 120-132.

69. Landon, M.K.; Rus, D.L.; Harvey, F.E. Comparison of instream methods for measuring hydraulic conductivity in sandy streambeds. Ground Water 2001, 39, 870-885.

70. Baxter, C.V.; Hauer, F.R. Geomorphology, hyporheic exchange, and selection of spawning habitat by bull trout (Salvelinus confluentus). Can. J. Fish. Aquat. Sci. 2000, 57, 1470-1481.

71. Butler, J.J.; McElwee, C.D.; Liu, W. Improving the quality of parameter estimates obtained from slug tests. Ground Water 1996, 34, 480-490.

72. Krause, S.; Bronstert, A.; Zehe, E. Groundwater-surface water interactions in a North German lowland floodplain-Implications for the river discharge dynamics and riparian water balance. J. Hydrol. 2007, 347, 404-417.

73. McDonnell, J.J. Are all runoff processes the same? Hydrol. Process. 2013, 27, 4103-4111.

74. Tromp-van Meerveld, H.J.; McDonnell, J.J. Threshold relations in subsurface stormflow: 2. The fill and spill hypothesis. Water Resour. Res. 2006, 42, doi:10.1029/2004WR003800.

75. Gabrielli, C.P.; McDonnell, J.J.; Jarvis, W.T. The role of bedrock groundwater in rainfall-runoff response at hillslope and catchment scales. J. Hydrol. 2012, 450-451, 117-133.

76. Woessner, W.W. Stream and fluvial plain ground water interactions: Rescaling hydrogeologic thought. Ground Water 2000, 38, 423-429.

77. Harvey, J.W.; Bencala, K.E. The Effect of streambed topography on surface-subsurface water exchange in mountain catchments. Water Resour. Res. 1993, 29, 89-98.

(C) 2014 by the authors; licensee MDPI, Basel, Switzerland. This article is an open access article distributed under the terms and conditions of the Creative Commons Attribution license (http://creativecommons.org/licenses/by/4.0/) 